\title{
Impact of student teaching experiences, personal demographics, and selected factors on the decisions of pre-service agricultural education teachers to enter into teaching
}

\author{
Gene Allen Hovatter \\ West Virginia University
}

Follow this and additional works at: https://researchrepository.wvu.edu/etd

\section{Recommended Citation \\ Hovatter, Gene Allen, "Impact of student teaching experiences, personal demographics, and selected factors on the decisions of pre-service agricultural education teachers to enter into teaching" (2002). Graduate Theses, Dissertations, and Problem Reports. 1468. \\ https://researchrepository.wvu.edu/etd/1468}

This Thesis is protected by copyright and/or related rights. It has been brought to you by the The Research Repository @ WVU with permission from the rights-holder(s). You are free to use this Thesis in any way that is permitted by the copyright and related rights legislation that applies to your use. For other uses you must obtain permission from the rights-holder(s) directly, unless additional rights are indicated by a Creative Commons license in the record and/ or on the work itself. This Thesis has been accepted for inclusion in WVU Graduate Theses, Dissertations, and Problem Reports collection by an authorized administrator of The Research Repository @ WVU. For more information, please contact researchrepository@mail.wvu.edu. 


\title{
Impact of Student Teaching Experiences, Personal Demographics, and Selected Factors on the Decisions of Pre-Service Agricultural Education Teachers to Enter into Teaching
}

\author{
Gene A. Hovatter
}

Thesis submitted to the Davis College of Agriculture, Forestry, and Consumer Sciences at West Virginia University in partial fulfillment of the requirements for the degree of

\author{
Master of Science \\ in \\ Agricultural and Environmental Education
}

Harry N. Boone, Ph.D., Chair

Layle D. Lawrence, Ph.D.

Kerry S. Odell, Ph.D.

Stacy A. Gartin, Ph.D.

Jean M. Woloshuk, Ed.D.

Division of Resource Management

Morgantown, West Virginia

2002

Keywords: Agricultural Education, Student Teaching, Career Decisions 


\section{Abstract \\ Impact of student teaching experiences, personal demographics, and selected factors on the decisions of pre-service agricultural education teachers to enter into teaching}

\section{Gene A. Hovatter}

With numerous openings in the agricultural education field and shortages constantly occurring, a common question is asked, "Why are pre-service teachers not teaching?" This study sought to help answer this question by investigating the impact of the student teaching experience upon certified agricultural education graduates. In addition to the student teaching experience, personal demographics and selected factors were investigated to add insight into the problem of pre-service agricultural education teachers not teaching. A two-phase descriptive survey methodology was implemented to collect data from the population, which consisted of 75 preservice agricultural education students from Delaware Valley College, Pennsylvania State University, University of Delaware, and West Virginia University. Responses from the phase one mail survey were used to formulate the phase two questionnaire. Responses from the phase two questionnaire were tabulated to measure the impact of the student teaching experience, personal demographics, and selected factors upon the graduate's decision to teach. 
This thesis is dedicated to my parents who were always supportive of my academic pursuits and who never stopped me from attaining my educational goals. My parents helped provide the motivation for me to carry on when I struggled and provided understanding when I spent so much time at college working towards my graduate degree. 


\section{Acknowledgements}

I wish to express my sincere gratitude to my graduate advisor, Dr. Harry N. Boone, for the constant encouragement and insight he gave me during my graduate program. The best part in being his advisee is that he always had time to help me, even when he was busy, he tried to help me and steer me in the right direction. I really appreciate the time and effort that Dr. Boone has devoted to my work. Thank you Dr. Boone.

I would also like to give special thanks to Dr. Kerry S. Odell who gave me the opportunity to be his teaching assistant. With this assistantship I was able to attend graduate school and pursue the degree that I wanted. I would also like to thank Dr. Odell for his time and effort to make things clearer when they seemed too far to reach.

A special thanks is also given to the rest of the members of my committee that includes:

Dr. Jean M. Woloshuk, Dr. Layle D. Lawrence, and Dr. Stacy A. Gartin. Without their help and their willingness to be on my committee, the attainment of my graduate degree would have remained a dream. Thanks are also given to Alice Compton who always had time to make copies and to be sure that I had my instruments in the mail and on their way.

I would like to give special thanks to my fellow graduate students, who provided friendship and counsel when the workloads seemed to be too much. Without their humor and sincerity, I would have gone crazy during my graduate studies.

Completion of my graduate degree would have not been possible without the help of the Agricultural and Environmental Education program in the Davis College of Agriculture, Forestry, and Consumer Sciences. The Delaware Valley College, Pennsylvania State University, and the University of Delaware are also acknowledged for their help in collecting data for my research. 


\section{Table of Contents}

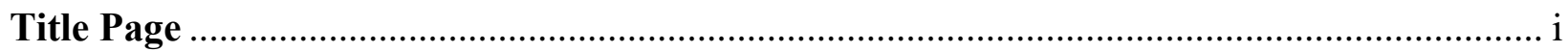

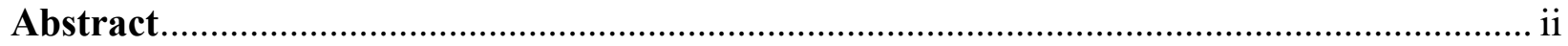

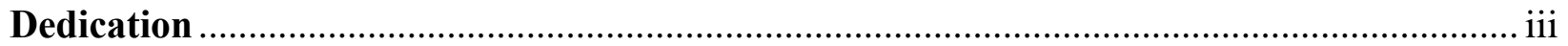

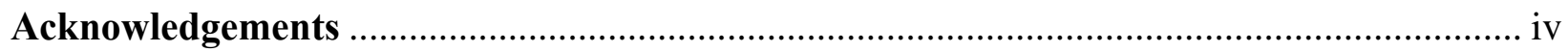

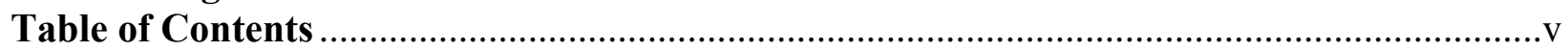

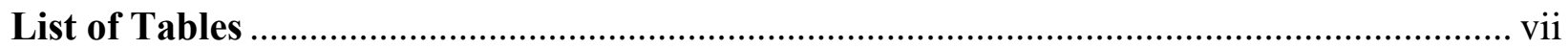

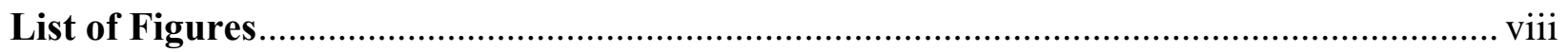

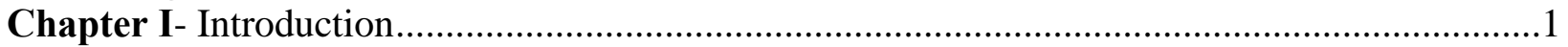

Background and Setting ......................................................................................

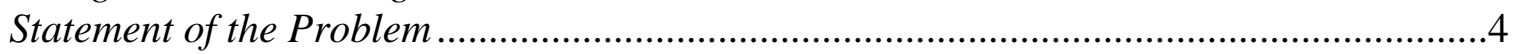

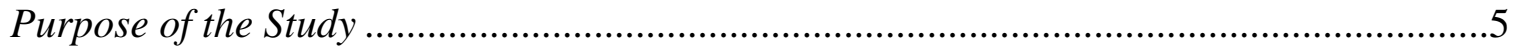

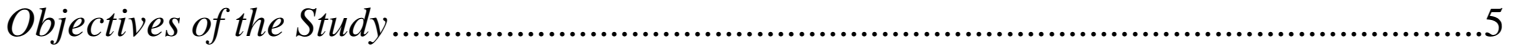

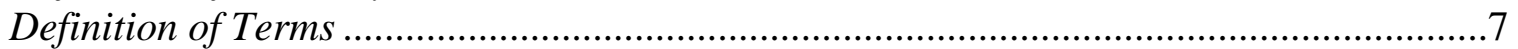

Limitations of the Study ......................................................................................

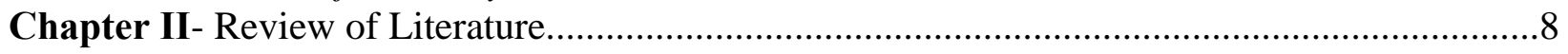

Student Teaching Experience ……………………...............................................

Demographic Characteristics ................................................................................10

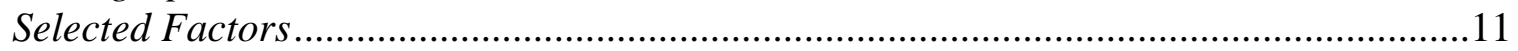

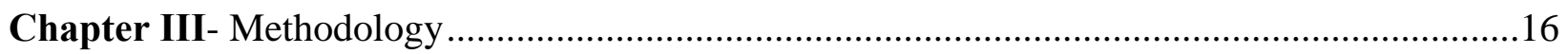

Population and Sample …………………………….........................................17

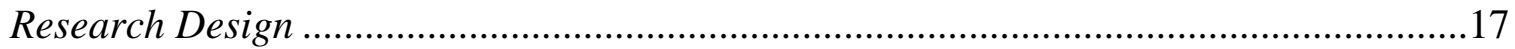

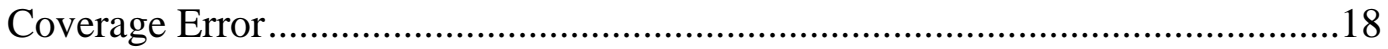

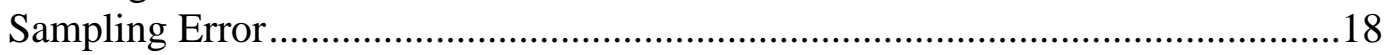

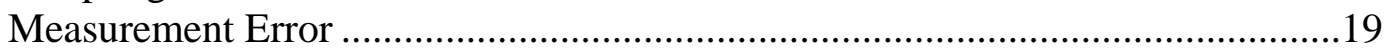

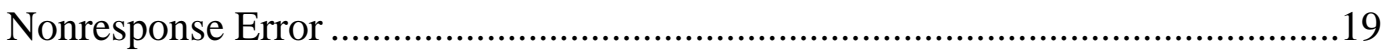

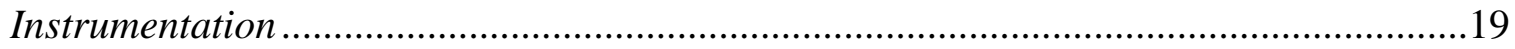

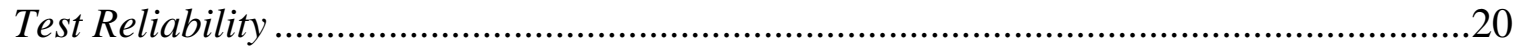

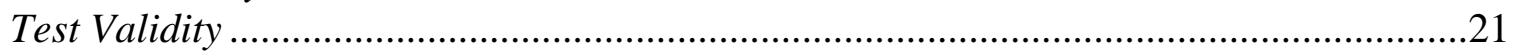

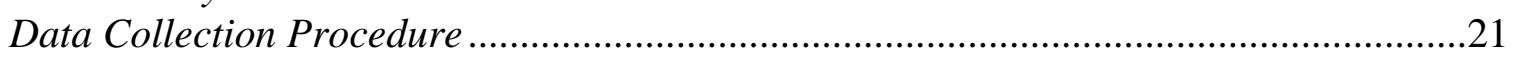

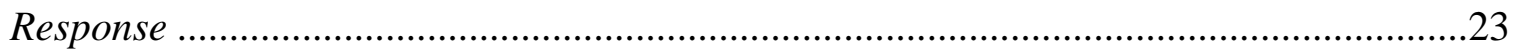

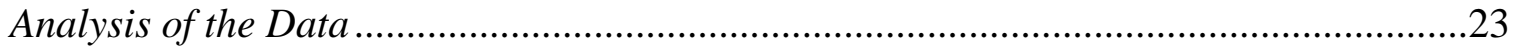

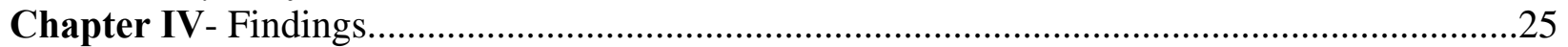

Distribution of Respondents by Institution .................................................................2

Demographic Characteristics ...............................................................................26

Distribution of Respondents by Teaching Status …………............................................30

FFA Membership in High School ...............................................................................33

Student Organization Membership in College ……………...............................................34

Relationships with Supervising and Cooperating Teachers .............................................35

Number of Years in Agricultural Classes .......................................................................3

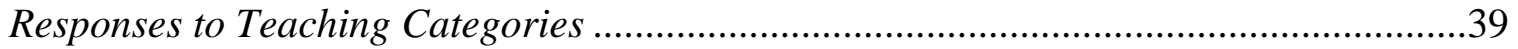

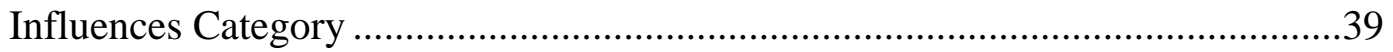

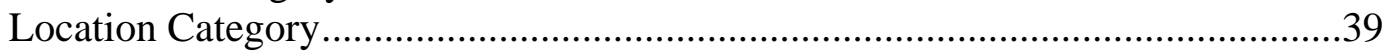

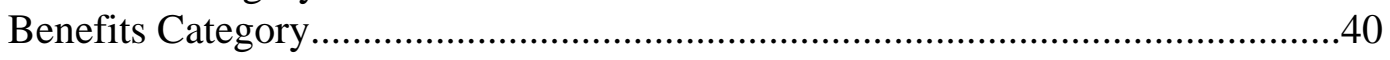

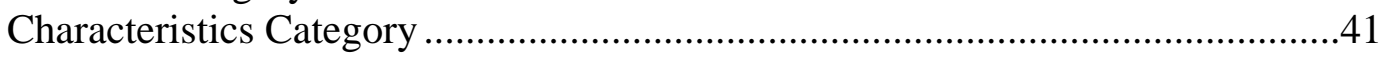




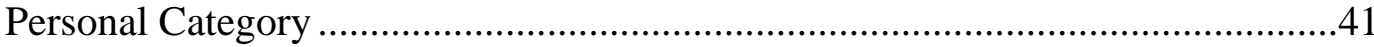

Responses to Non-teaching Categories .........................................................................43

Teaching Category ……………………....................................................44

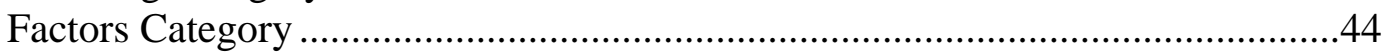

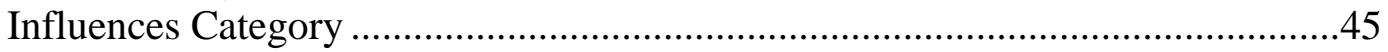

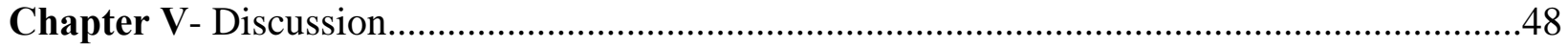

Purpose of the Study ............................................................................................48

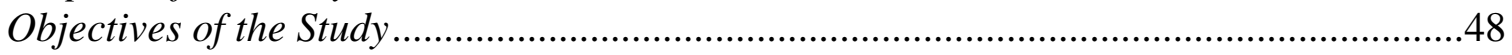

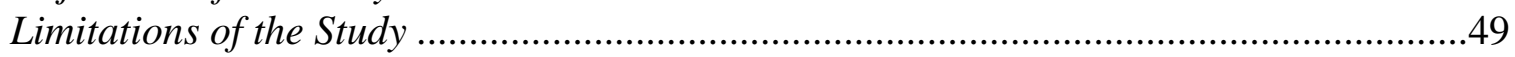

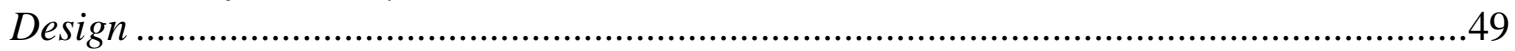

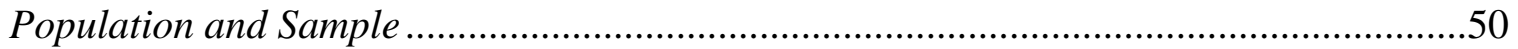

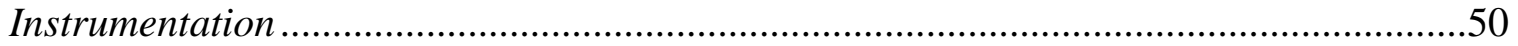

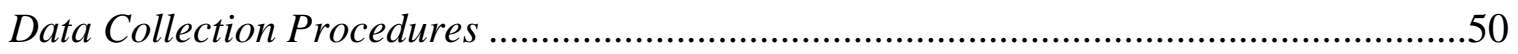

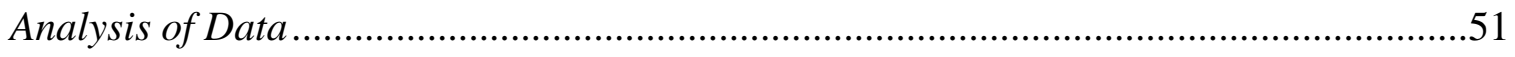

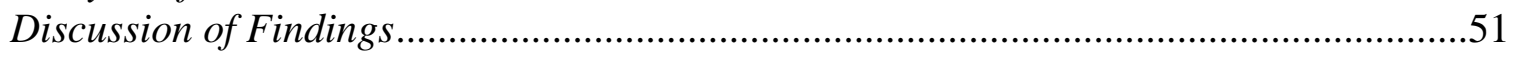

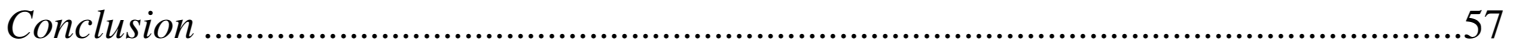

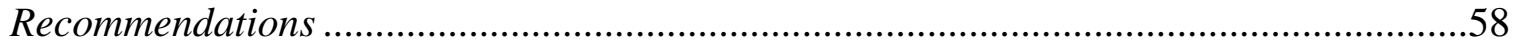

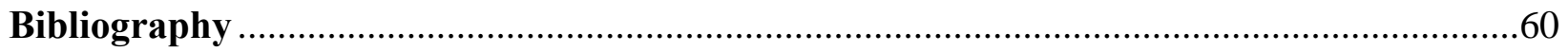

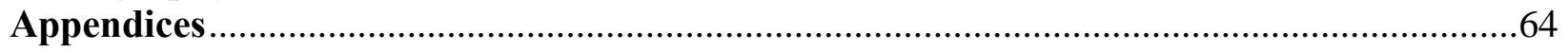

Appendix A: A Letter of Introduction Mailed with Phase One Survey................................65

Appendix B: Phase One Survey ..........................................................................................67

Appendix C: Reminder Post Card Mailed During Phase One............................................69

Appendix D: A Letter of Explanation Mailed with Phase Two Questionnaire ......................71

Appendix E: Phase Two Questionnaire ......................................................................

Appendix F: Reminder Post Card Mailed During Phase Two..........................................8

Appendix G: Distribution of Teaching Responses from the Questionnaire ..........................84

Appendix H: Distribution of Teaching Responses in the Influences Category .....................87

Appendix I: Distribution of Teaching Responses in the Location Category .........................89

Appendix J: Distribution of Teaching Responses in the Benefits Category ........................91

Appendix K: Distribution of Teaching Responses in the Characteristics Category ..............93

Appendix L: Distribution of Teaching Responses in the Personal Category ........................95

Appendix M: Distribution of Non-teaching Responses from the Questionnaire...................97

Appendix N: Distribution of Non-teaching Responses in the Teaching Category ..............100

Appendix O: Distribution of Non-teaching Responses in the Factors Category .................102

Appendix P: Distribution of Non-teaching Responses in the Influences Category............104

Appendix Q: Comments from Respondents to the Questionnaire......................................106

Appendix R: Copy of Approval from the Institutional Review Board for the

Protection of Human Subjects ........................................................................108

VITA 


\section{List of Tables}

Table

Page

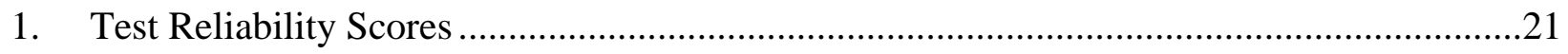

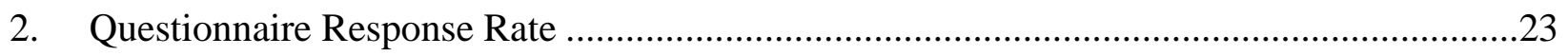

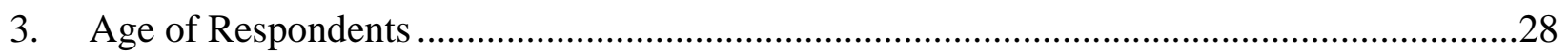

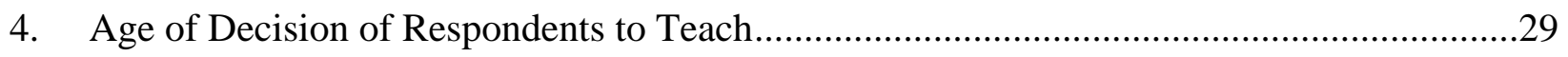

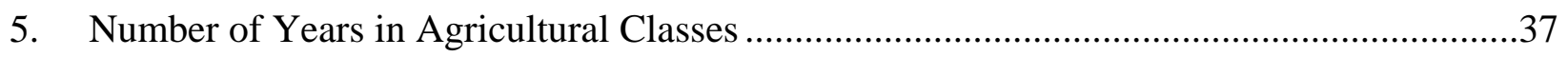

6. Distribution of Respondents to the Different Teaching Categories..................................42

7. Distribution of Respondents to the Different Teaching Categories by Institution ...............42

8. Distribution of Respondents to the Different Teaching Categories by Institution ...............43

9. Distribution of Respondents to the Different Non-Teaching Categories.............................46

10. Distribution of Respondents to the Different Non-Teaching Categories by Institution ........46

11. Distribution of Respondents to the Different Non-Teaching Categories by Institution ........47

G-1. Distribution of Teaching Responses from the Questionnaire ......................................85

H-1. Distribution of Teaching Responses in the Influences Category ..................................89

I-1. Distribution of Teaching Responses In the Location Category ...................................91

J-1. Distribution of Teaching Responses in the Benefits Category ......................................93

K-1. Distribution of Teaching Responses in the Characteristics Category.............................95

L-1. Distribution of Teaching Responses in the Personal Category .....................................97

M-1. Distribution of Non-Teaching Responses from the Questionnaire .................................99

N-1. Distribution of Non-Teaching Responses in the Teaching Category .............................102

O-1. Distribution of Non-Teaching Responses in the Factors Category ................................104

P-1. Distribution of Non-Teaching Responses in the Influences Category...........................106 


\section{List of Figures}

Figure

Page

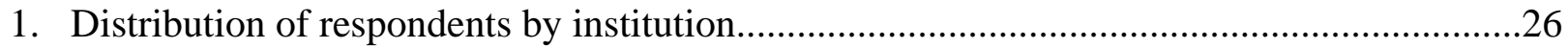

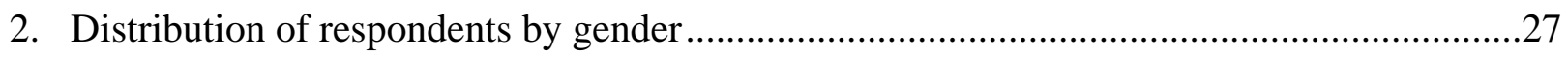

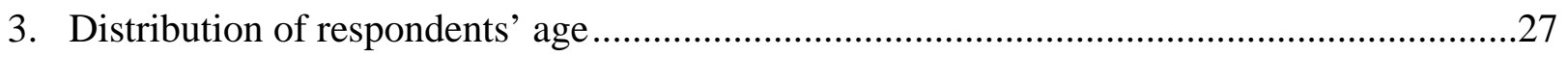

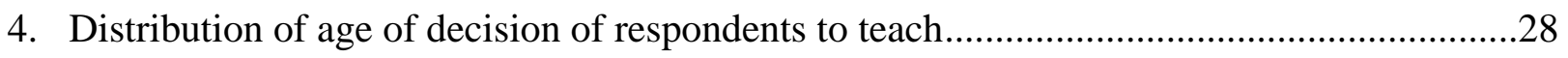

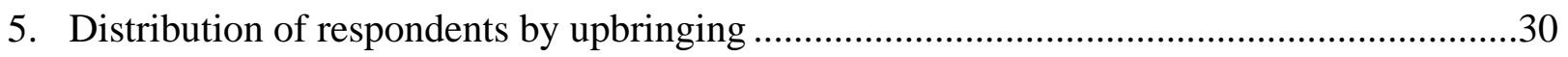

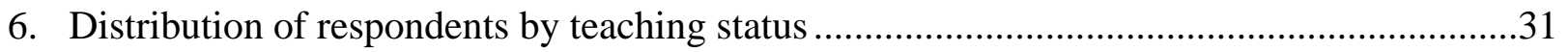

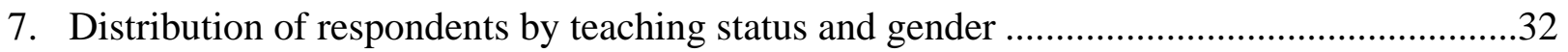

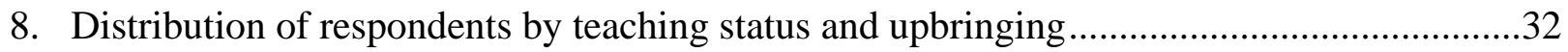

9. Distribution of respondent by teaching status and average number of years in agricultural

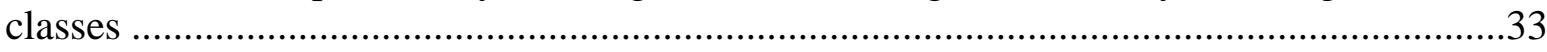

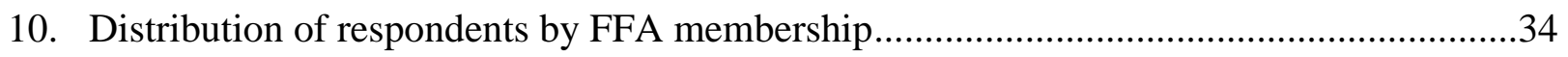

11. Distribution of respondents by college organization membership .................................35

12. Distribution of respondents by positive cooperating teacher relationship........................36

13. Distribution of respondents by positive University supervisor relationship......................37

14. Distribution of respondents by years in agricultural classes and by institution..................38

15. Distribution of respondents by number of years in agricultural classes ..........................38 


\section{Chapter I}

\section{Introduction}

\section{Background and Setting}

The importance of a teacher's role has been exemplified many times over the decades by some of the greatest minds in history. Albert Einstein once said, "It is the supreme art of the teacher to awaken joy in creative expression and knowledge" (as cited by the Liberty Classical School). Without teachers to guide the process, student learning could be minimized or not even occur. Education needs a constant supply of teachers to make sure that the youth of our nation receive a quality education and are given an opportunity to learn.

The shortage of teachers is a major problem and threatens to overwhelm the educational system in the United States. Ingersoll (1995) stated, "At the beginning of both the 1987-88 and 1990-91 school years, an overwhelming majority of schools had job openings for teachers" (p. 6). The sheer numbers seem more vivid with the results from a study published by the National Center for Education Statistics in which they found, "In high-poverty urban and rural districts alone, more than 700,000 new teachers will be needed in the next 10 years" (as cited by the National Education Association [NEA], 2001, The search for qualified teachers section, II 4).

There are those who argue that a teacher shortage does not exist. Wayne (2000) stated: Projections show that enrollments are leveling off. Relatedly, annual hiring increases should be only about two or three percent over the next few years. Results from studies of teacher attrition also yield unexpected results. Excluding retirements, only about one in twenty teachers leave each year...(p. 1). 
Future predictions on current teacher supply differ as noted by the National Center for Education Statistics, "Nationwide some 2.4 million teachers will be needed in the next 11 years because of teacher attrition and retirement and increased student enrollment"(as cited by the NEA, 2001, The search for qualified teachers section, II 1). Ingersoll (1995) offered a possible reason for the teacher shortage not appearing. He found several strategies that schools used to fill open teaching positions, unfortunately positions being filled by these strategies resulted in “...teacher quality has been rendered for teacher quantity, rendering the teacher shortage invisible" (p. 6). Despite studies showing that there is not a teacher shortage, evidence by Hammond (2000) noted otherwise, "The most well-reasoned estimates place the total demand for new entrants to teaching at 2 to 2.5 million between 1998 and 2008, averaging over 200,000 annually" (p. 11).

Since there is such a shortage of teachers in all fields, one might ask:

- Why are more pre-service teachers not entering the field of teaching?

- What can be done to insure that pre-service teachers enter the field of teaching?

Many think the shortage is a result of the problems or hardships associated with teaching, even though teaching is considered to be a noble career. In fact, teaching has been seen as a prominent career that involves caring persons devoting their life to educate youth. Most teachers stated that, "they began teaching because they wanted to work with young people" (NEA, 1997, Why do teachers teach section, II 1). The satisfaction of teaching young people is evident by the fact that most teachers find their careers to be rewarding and enjoyable. The National Education Association (1997) noted, "The percentages of teachers who would choose teaching again has increased steadily since 1981, indicating that teachers are satisfied with their 
profession. Some 62.6 percent of all teachers said they certainly or probably would become a teacher again" (Why do teachers teach section, If 2).

Previous studies, have also expressed concerns about the lack of teachers or teachers leaving the profession. "If trends of the past continue into the future, the overwhelming majority of these new teachers will not be found in the classroom five years from now" (Lohman, Kurash, \& Chiu, 1966, p. 2). As early as 1957 , this was a problem that continually surfaced and was researched. The National Education Association reported, "Thousands of new teachers are required each year to replace those who, though well prepared, have successful records and are capable of many more years of effective service, nevertheless leave the profession" (Lohman et al., 1966, p. 2). Over the decades, the teacher shortage problem has continued. This was evident by continued studies in this area (e.g., Cheng, 1983; Zclarzek, Williams, McAdams, \& Palmer, 1999).

This information is relevant to all education teachers, including the field of agricultural education. Research conducted to identify factors associated with a teacher shortage problem in agriculture discovered four dominant factors. According to a study completed by Craig (1988), the dominant factors were:

1) state and national recruitment efforts have been inconsistent in enrolling sufficient agricultural education students; 2) the competition continues from other agricultural fields when employing agricultural education graduates; 3) part of the shortage problem is caused by graduates who do not want to leave home to teach in another area of the state or another state; and 4) the decreasing number of graduates who choose to teach vocational agriculture (p. 11). 
To help answer the questions about why many pre-service agricultural education teachers are not teaching and to increase the number of pre-service agricultural education teachers who enter teaching, the factors influencing people to enter into the agricultural educational field and stay must be examined. The number of students completing their educational programs, including student teaching, but not entering into the teaching profession, should be determined. It has been shown that, "there has been increased placement of agricultural education graduates in other occupations" (Craig, 1988, p. 11). The critical decision period or the critical decision factor that determines if a graduate enters the field of teaching or not should be established.

Strong concerns were raised in 1988, when Craig (1988) remarked, "Given the rapid decrease in agricultural education graduates in recent years (20 percent from 1985-1986) and the continued low placement rate in vocational agriculture teaching (41 percent), a new teacher shortage could occur in two or three years" (p. 12). In 2000, Camp found seventy agricultural education teaching positions were available with no teachers to fill them.

\section{Statement of the Problem}

Teaching vacancies in agricultural education are continuous because of teacher attrition, retirement, and increased enrollments. This occurrence is natural and happens in every occupation, but in agricultural education a problem exists because there are not enough teachers to fill the vacancies. The shortage of agriculture teachers was evident in research conducted by Camp (2000). Results from his research on the supply and demand of teachers in agricultural education in 1998 showed a severe teacher shortage. In 1995, his research found 889 openings with the net number of 575 new teachers needed. In 1998, there were 70 agriculture teachers needed but not available on September 1. The study demonstrated that there were simply not enough teachers to fill all of the positions that were available. The real problem is not in the 
number of teachers needed but the number of qualified teachers seeking teaching positions. In 1997 there were 748 newly qualified teachers, however, only $619(83 \%)$ were seeking teaching positions (Camp, 2000). The difference was 129 newly qualified potential teachers not entering the field of teaching in agricultural education. If the current trend continues, then there will be increasing number of positions open but not enough teachers willing to fill them. This will lead to program closures and high school students losing the opportunity to prepare for careers in agriculture.

Purpose of the Study

The purpose of this study was to provide information to colleges, teacher educators, and school districts regarding the characteristics of pre-service agricultural education teachers who enter teaching and the relationship of the student teaching experience on their decision to teach. Objectives of the Study

The primary objective of this study was to determine the impact of the student teaching experience upon the decision of the pre-service agricultural education teacher of the Five Star Consortium who graduated from 1998-2001 to enter into teaching.

Secondary objectives for this study were to determine the impact of the personal demographics and other selected factors on the decision of pre-service agricultural education teachers to enter into teaching. Upon completion of the study, a list of characteristics common to pre-service agricultural education teachers planning to teach will be established. A better understanding of characteristics common to pre-service agricultural education teachers will allow universities, colleges, and school districts to better predict the availability of filling teaching openings, as well as predicting teacher shortages.

The primary research question investigated was: 
Does the student teaching experience have the greatest impact on the decision of the preservice agricultural education teacher to enter the teaching profession?

In addition to the primary question, nine alternative questions were considered:

1. Does the gender of the pre-service agricultural education teacher have an impact on his/her decision to enter the teaching profession?

2. Does the upbringing of the pre-service agricultural education teacher have an impact on his/her decision to enter the teaching profession?

3. Does the age of the pre-service agricultural education teacher have an impact on his/her decision to enter the teaching profession?

4. Does the age of decision of the pre-service agricultural education teacher have an impact on his/her decision to enter the teaching profession?

5. Do the outside influences of the pre-service agricultural education teacher have an impact on his/her decision to enter the teaching profession?

6. Does FFA involvement of the pre-service agricultural education teacher have an impact on his/her decision to enter the teaching profession?

7. Does the number of years in agriculture classes of the pre-service agricultural education teacher have an impact on his/her decision to enter the teaching profession?

8. Do the characteristics of teaching have an impact on the decision of the pre-service agricultural education teacher to enter the teaching profession?

9. Does participation in college organizations have an impact on the decision of the preservice agricultural education teacher to enter the teaching profession? 


\section{Definition of Terms}

Age of Decision: The critical age in an individual's life when they decide upon the career that they plan to pursue.

Cooperating Teacher: During student teaching, the cooperating teacher is the high school teacher who directs and supervises the day-to-day activities of the student teacher.

FFA: A national organization, that was previously named the Future Farmers of America, whose mission is to make a positive difference in the lives of students by developing their potential for premier leadership, personal growth and career success through agricultural education. Five Star Consortium: An organization of states including: West Virginia, Maryland, Pennsylvania, New Jersey, and Delaware, whose mission is to promote Agricultural and Environmental Education through professional development.

Student teaching: A requirement in the preparation of teachers that involves actual classroom application of technical and pedagogical knowledge and skills; usually completed during the senior year and lasts for about fifteen weeks.

University Supervisor: A selected college professor that supervises and gives advice to the student while they are participating in their student teaching

\section{Limitations of the Study}

This study was limited to the perceptions of pre-service agricultural education teachers from 1998-2001, who attended Delaware Valley College, Pennsylvania State University, and/or West Virginia University. 


\section{Chapter II}

\section{Review of Literature}

Many factors seem to influence the choice to enter into the teaching profession following the student teaching experience. To better understand the roles these factors play in the teaching/career decisions of the pre-service agricultural education teachers, careful consideration must be given to each.

Student Teaching Experience

One common characteristic of most pre-service agricultural education teachers is they have field training with teaching experiences, commonly referred to as student teaching, during their college preparation. Student teaching is the application of the technical and pedagogical knowledge and skills acquired in college to real high school teaching situations. The experience of student teaching is important because, "This application of theory in the real world (classroom) helps the student teacher to begin to develop a teaching style" (Andrews, 1964, p. 8). The student teaching experience helps develop a person into an effective teacher. Without this experience, the student teacher may be prepared inadequately for a full-time teaching career. Student teaching for some students can be an exciting event and for others it may seem to be an overwhelming event, but overall student teaching plays many roles in the teaching/career decisions of pre-service agricultural education teachers.

Theories proposed on the basis for student teaching state, "Knowledge is not power until it is applied; before the application is made, it is only potentiality. Facts, principles, and theories are useless unless applied to situations to which they are relevant” (Mead, 1930, p. 4). From these theories one can conclude that the student teaching experience has a role in agricultural 
education teachers' decisions on whether to teach. In a study conducted by Moss and Rome in 1990, the results highlight the importance of the student teaching experience.

First year teachers, university supervisors, and cooperating classroom teachers agreed that student teaching was the most valuable component of the teacher education program and disagreed with the statements, student teacher's work loads are too heavy and student teachers learn very little from student teaching (p. 31).

The main premise behind the theories on student teaching were best noted by Aristotle, "We learn by doing" (as cited by the Liberty Classical School). One of the many roles of the student teaching experience is to "help the student make a realistic evaluation concerning his/her interest in and aptitude for teaching" (Franklin College, 2000, Purposes of Field Experiences and Student Teaching section, para. 1). Without the direct application of the theories and techniques of teaching, a student teacher may have an idealized view of teaching and be intimidated by the actual requirements of the profession.

Associated with the student teaching experience is the relationship with the student's university supervisor and cooperating teacher. The university supervisor/student teacher relationship can influence the student teaching experience. If a good relationship exists with the student teacher, this can lead to a positive student teaching experience. On the other hand, if the student teacher has a bad relationship with the university supervisor it may lead to a negative student teaching experience. The situation with the cooperating teacher is similar. If the relationship is bad between the cooperating teacher and the student teacher, a negative student teaching experience may result. A good relationship is conducive to a positive student teaching experience. 


\section{Demographic Characteristics}

Demographic characteristics are directly related to each agricultural education major and his/her basis for thinking or for making decisions. In studies completed on the characteristics of agricultural education teachers, it was noticed that demographic characteristics provide both background of the pre-service agricultural education teachers and also insight into why they may make the decisions they do. A study completed by Lohman, Kurash, and Chiu (1966) provides evidence of demographic characteristics that surface in teaching. For example, they noted that “Teaching as a career field attracts more women than men" (Lohman et al., 1966, p.2). In a study by Soh (1983) there was continued evidence of the gender gap in teaching. Soh (1983) stated, "It is however necessary to point out that there was an obvious female preponderance in the 1981 group of graduates whereas there was a better balance between the sexes in the 1968 group of graduates" (p. 18). With these findings there is strong evidence that teaching, in general, attracts more females than males.

Another factor that affects the decision making process of pre-service agricultural education teachers is where the pre-service agricultural education teacher was reared. The two major areas of interest are the urban area and the rural area. In a study of fifty graduates, "only seventeen of the fifty graduates studied had taken two years or more of vocational agriculture in high school, but 39 of these men came from farms" (Hemp, 1957, p. 165). Overall, the percentage of rural area students that composed the fifty graduates was $78 \%$. The major problem is that the differences between the areas are not always clear. A study by Hillison and Hagee (1980) in Virginia found, "Few of the agricultural education students in this study had a farm background" (p. 4). Rapid decreasing farmland as noted by Senator Katie Wolf (n.d), “Across the country, 50 acres of farmland are lost to development every hour" (II 1), can affect the 
amount of area that pre-service agricultural education teachers can come from and results in fewer pre-service agricultural education teachers coming from farm backgrounds.

Age is another factor that seems to play a role in the decision making of pre-service agricultural education teachers. The factor of age has been divided into two groups, age of the person and age at the time of their decision to teach. It is important that age of the person be considered in the factors that may lead pre-service agricultural education teachers to enter the profession.

Age of decision to teach is the other category that should be analyzed. Age of decision has been shown to have some impact on other factors that influence pre-service agricultural education teachers. In a study that compared 1968 and 1981 research, it was found that, "As compared with those of the earlier study (1968), graduates in the present study recalled an earlier age of decision to teach; the difference is about five years" (Soh, 1983, p. 52). The results show that there is a trend or influence from the age of decision. One explanation for this occurrence was, "Yet, the difference in the recalled age of decision to teach seems to indicate that the students were more keen to come up and work" (Soh, 1983, p. 52). The final product from this interaction has been an increasing younger age of teachers. "The typical teacher is 43 years old (66.9\% are 40 years of age or older; 10.7\% are below 30)" (NEA Today, 1996, Who are Today's Teachers?).

\section{Selected Factors}

The factors that were not related to the student teaching experience or the demographic characteristics but included in the study were, outside influences, FFA involvement, years in agriculture, and influence from the characteristics of teaching itself. These factors were harder to 
measure but important in analyzing which factors may have the greatest impact in the decision making of pre-service agricultural education teachers.

Outside influences can be from the family of the pre-service agricultural education teacher or from their high school agricultural teacher. The influences from the family can be as indirect as a teacher in the family or as direct as family members encouraging the pre-service agricultural education teacher to pursue teaching.

The influence of having a teacher in the family should have an impact on pre-service agricultural education teachers but actually there was some contradiction to this, "Between these two groups of graduates (1968-1981), there was no difference in the proportion of respondents who came from families with a teacher" (Soh, 1983, p. 23). Even teachers that are in families don't influence the decision of fellow education teachers in their family. The data from a study by Soh (1983) displayed some evidence that the incidence of having a teacher in the family is actually going down, teacher in the family with female graduates $1981(n=69)=34.8$ and 1968 $(n=69)=43.5$ (Soh, 1983, p. 26). There were no exact figures given for males. These figures represent percentages to the respective group size. One important fact to keep in mind when looking at this factor is that the population has increased over the years while the number of teachers has declined.

The influence from the family can be from the parents or a sibling. Individually this influence may have an effect but over a group this factor does not seem to be very influential. On a 1-30 scale, with one being the highest influence and 30 being the lowest influence, Hillison and Hagee (1980) found, Family/Home Influences = 5.65 (p. 8). One unique relationship that was shown by Hillison and Hagee (1980) is that, the Family/Home Influences was higher in males (6.53) than females (4.74) (p. 9). Even though the influence from the family may not be as 
great as proposed, this evidence demonstrates that family influences can exert an impact on preservice agricultural education teachers.

One influence appeared strong in the decision of pre-service agricultural education teachers to teach was their high school agriculture teacher. Evans (as cited in Hillison and Hagee, 1980) found that vocational agriculture teachers were the most influential factor for students selecting agricultural education as a major. In the study completed by Hillison and Hagee (1980), evidence was shown about the significance of the influence from teachers, "Males give instructor influences a mean rating of 12.19 , while females rated it 9.11 ” (p. 10). This denoted very strong evidence about the high school agriculture teacher's influence on pre-service agricultural education teachers. Instructor's influences were in the top three influences in males and in the top five influences in females.

The FFA is seen as an organization that helps develop leadership abilities in high school and collegiate students and allows them to participate in a national organization. With much of the emphasis of the FFA being on agriculture, pre-service agricultural education teachers who were in this organization may have been influenced to a greater degree to teach. Hillison and Hagee (1980) found "Undergraduate students who had taken vocational agriculture rated high school vo-ag and FFA experiences as the most influential factor" (p. 17). Hillison and Hagee noted that male respondents in their study rated high school vocational agriculture and FFA experiences as the second highest influence and females rated it as the seventh highest influence.

Years enrolled in agricultural classes have been shown to have a definite influence on the choice of pre-service agricultural education teachers to teach, "Luft found that 37 percent of the students enrolled in agricultural education teacher preparation programs had taken four years of vocational agriculture" (as cited in Hillison \& Hagee, 1980, p. 4). A relationship between years 
in vocational agriculture and the career choice of pre-service agricultural education teachers to teach is further evidenced in Hillison and Hagee's (1980) finding that, "students who enrolled in vocational agriculture for five years, chose a career in agricultural education at a younger age than students enrolled in vocational agriculture for a fewer number of years" (p. 26).

The last factor selected for this study was the influence from the characteristics of teaching. These characteristics of teaching can range from salaries of teachers, positions available, advancement of agricultural education, interaction with young people, interest in the subject matter, an interesting job, and a challenging job. Even though this category seems to be broad there were actually only a few specific characteristics that stood out when determining the factors that influence pre-service agricultural education teachers to teach. One of the predominant factors was the ability to interact or work with young people. "The majority of teachers say they began teaching because they wanted to work with young people. In fact, this desire has been the primary reason teachers have given for choosing their profession since the survey question was first asked in 1971" (National Education Association, 1996, Why do teachers teach section, II 2).

In the study done by Hillison and Hagee, other characteristics of teaching seemed to play a part in the decision to teach. "For males, economic/ social categories (13.93) and for females, personal reasons (16.57)", played a role (Hillison \& Hagee, 1980, p. 9). Males in that study were more interested in economical/social categories which included: agricultural education is a good way to get into other jobs, agricultural education has a lot of geographical mobility, and there is a strong demand for agricultural teachers. Females were more interested in personal reasons that included: working with young people, wanted to be my own boss, and a wanting to share an interest in my technical agriculture field with others. Differences can be seen, but it displays 
definite proof that these characteristics of teaching should be examined when looking at what influences pre-service agricultural education teachers to teach.

With the research differing on the impacts and influences that cause a pre-service agricultural teacher to teach, many of the same factors must also be looked at in this study. The student teaching experience must be examined to see if it has a strong impact on a pre-service agricultural education teacher to enter the profession. Demographic characteristics must be examined to see if trends of the past coincide with the pre-service agricultural education teachers of the present. Selected factors of the pre-service agricultural education teacher must be examined to see what aspects of teaching impact pre-service agricultural education teachers and to see what problems or difficulties of teaching impact pre-service agricultural education teachers. All of these different factors must be examined to find out which factors have the strongest impact on the decisions of pre-service agricultural education teachers to that measures can be implemented to help retain pre-service agricultural education teachers into the field of teaching. 


\section{Chapter III}

\section{Methodology}

This study was designed to explore the impact of student teaching experiences, personal demographics, and selected factors upon the decisions of pre-service agricultural education teachers to enter into teaching. The purpose of this study was to provide information to colleges, teacher educators, and school districts regarding common characteristics of pre-service agricultural education teachers who enter teaching and the relationship of the student teaching experience and their decision to teach.

Guiding this study were a primary research question and nine alternate research questions. The primary research question states:

Does the student teaching experience have the greatest impact on the decisions of preservice agricultural education teachers to enter the teaching profession?

The nine alternate research questions state:

1. Does the gender of the pre-service agricultural education teacher have an impact on his/her decision to enter the teaching profession?

2. Does the upbringing of the pre-service agricultural education teacher have an impact on his/her decision to enter the teaching profession?

3. Does the age of the pre-service agricultural education teacher have an impact on his/her decision to enter the teaching profession?

4. Does the age of decision of the pre-service agricultural education teacher have an impact on his/her decision to enter the teaching profession?

5. Do the outside influences of the pre-service agricultural education teacher have an impact on his/her decision to enter the teaching profession? 
6. Does FFA involvement of the pre-service agricultural education teacher have an impact on his/her decision to enter the teaching profession?

7. Does the number of years in agriculture classes of the pre-service agricultural education teacher have an impact on his/her decision to enter the teaching profession?

8. Do the characteristics of teaching have an impact on the decision of the pre-service agricultural education teacher to enter the teaching profession?

9. Does participation in college organizations have an impact on the decision of the preservice agricultural education teacher to enter the teaching profession?

\section{Population and Sample:}

The target population was 75 pre-service agricultural education teachers who graduated between 1998-2001 from colleges serving the Five Star Consortium. Lists of pre-service agricultural education teachers were secured from the records held within the college's agricultural education departments. Since this study was a census, the frame for this study was the same individuals as the population and included all units (pre-service agricultural education teachers).

\section{Research Design}

A descriptive survey method, in the form of a census study, was utilized to obtain data for this study. This design was utilized to explore and describe the impact of the personal demographics, selected factors, and the perceptions of student teaching experiences of the preservice agricultural education teachers as influences of their decision to teach. Crowl (1993) stated that descriptive survey methods allow the researcher to, "observe and describe variables as they are distributed throughout a population" (as cited by Cashwell, n.d., What is descriptive research section, I[ 1). Descriptive research has also been defined by Ary, Jacobs and Razavieh 
(1985) as research that "describes and interprets what is. It is concerned with conditions or relationships that exist; practices that prevail; beliefs, points of view, or attitudes that are held; processes that are going on; effects that are being felt; or trends that are developing" (as cited by McCutcheon, 1995, p. 48).

Salant and Dillman (1994) note that there are four main errors that should be addressed with survey research to yield accurate results. These were: coverage error, sampling error, measurement error, and nonresponse error. These errors were eliminated or minimized in this study as follows:

\section{$\underline{\text { Coverage Error }}$}

Salant and Dillman (1994) defined coverage error as "occurring when the list-or framefrom which a sample is drawn does not include all elements of that population that researchers wish to study" (p. 16). The population for this study was all of the pre-service agricultural education teachers who graduated from Delaware Valley College, Pennsylvania State University, and West Virginia University between 1998 and 2001. Permanent college addresses were used to contact the population. Because students move following graduation, the college address list was not current for everyone in the population. This resulted in the inability to contact $100 \%$ of the target population.

\section{$\underline{\text { Sampling Error }}$}

"Sampling error occurs when researchers survey only a subset or sample of all people in the population instead of conducting a census" (Salant \& Dillman, 1994, p. 17). Conducting a census with the descriptive survey and including all of the usable population eliminated this error. 


\section{$\underline{\text { Measurement Error }}$}

Salant and Dillman (1994) defined measurement error as "occurring when a respondent's answer to a given question is inaccurate, imprecise, or cannot be compared in any useful way to other respondents' answers" (p. 17). Use of a mail survey helped reduce this error by giving the respondent time to answer the questions and letting them have the ability to fill out the questionnaire without external influences. Measurement error was also reduced by the use of a two-phase survey in which the respondents give replies to phase one and those replies are then used to construct phase two of the survey. Monitoring the validity and reliability of the instrument also minimized this error. Please see the test validity and test reliability sections for details.

\section{$\underline{\text { Nonresponse Error }}$}

"Nonresponse error occurs when a significant number of people in the survey sample do not respond to the questionnaire and are different from those who do in a way that is important to the study" (Salant \& Dillman, 1994, p. 20). Reduction in nonresponse error occurred by using recommended follow-up procedures including the use of follow-up postcards to remind individuals that their response had not been received. Comparison of late responses and early responses to the survey for similarity and consistency was conducted to determine if nonresponse error had occurred.

\section{Instrumentation}

A letter of introduction explaining the study, signed by the researcher and the faculty advisor, and a questionniare which asked the recipient to identify the top three reasons why they were currently teaching or the top three reasons why they were not currently teaching was prepared and sent to the population. The researcher developed a list of responses from the 
survey modeled after techniques used by O'Dell, (1982, p. 8) and Ellis (1990, p. 14). The list was then formulated into a second questionnaire that inquired into reasons for currently teaching or reasons for not currently teaching. The questionnaire was reviewed by a panel of experts consisting of faculty members of the Davis College of Agriculture, Forestry, and Consumer Sciences to establish its content validity. Participants in the study were asked to rate each of the items in the questionnaire on the following scale: 1 - strongly disagree, 2 - disagree, 3 - neutral, 4 - agree, and 5 - strongly agree. The questionnaire also included questions about the demographic characteristics of each participant and their current teaching status. Responses were analyzed for internal consistency reliability by the use of Cronbach's Alpha, which resulted in a questionnaire average coefficient of $r=.78$ for both the teaching and non-teaching sections of the questionnaire. See test reliability section for more information on the total questionnaire reliability.

The researcher and committee chairperson grouped the teaching responses from the questionnaire into five categories to help identify particular areas of strong impact. The five categories consisted of: influences, location, personal, teaching benefits, and teaching characteristics. The researcher and committee chairperson also grouped the non-teaching responses from the questionnaire into three categories to help identify particular areas of strong impact. The three categories are: teaching, factors, influences. Reliability coefficients were calculated for each category for teaching and non-teaching.

\section{Test Reliability}

Reliability is the "ability of a test (instrument) to yield consistent results" (Patten, 2000, p. 65). The internal consistency reliability was calculated using Cronbach's Alpha coefficient. Reliability for the overall questionnaire was $r=.78$. Reliability for the overall teaching portion 
of the questionnaire was $r=.66$ and was $r=.88$ for the non-teaching portion. The reliability from the teaching categories ranged from $r=.50$ to $r=.77(\mathrm{~N}=16)$. Reliability on the nonteaching categories ranged from $r=.62$ to $r=.95(\mathrm{~N}=16)$. Reliability coefficients are listed in Table 1.

Table 1

Test Reliability Scores

\begin{tabular}{lclc}
\hline Teaching Categories & $\boldsymbol{\alpha}$ & Non-teaching Categories & $\boldsymbol{\alpha}$ \\
\hline Personal & .77 & Non Teaching - Teaching & .95 \\
Benefits & .77 & Non Teaching - Influences & .95 \\
Influence & .68 & Non Teaching - Factors & .62 \\
Location & .60 & Non-Teaching Overall & .88 \\
Characteristics & .50 & & \\
Overall & .66 & & \\
\hline
\end{tabular}

\section{Test Validity}

Validity is the "ability of an instrument to measure what it is supposed to measure and perform the function that it was purported to perform" (Patten, 2000, p. 53). All parts of the phase two questionnaire were assessed for content and face validity by a panel of experts consisting of faculty members in agriculture and environmental education at the Davis College of Agriculture, Forestry, and Consumer Sciences at West Virginia University.

\section{Data Collection Procedure}

A census of the pre-service agricultural education teachers from the Five Star Consortium who graduated from 1998-2001 was the population for this study (N=75). Information from the population was gathered by the use of a two-phase descriptive survey method. Framework for the usage of a two-phase descriptive survey was gained from studies done by O'Dell (1982, p. 2- 
3), McCutcheon (1995, p. 49), and Ellis (1990, p. 13). A letter of introduction (Appendix A) explaining the study, signed by the researcher and the faculty advisor, and a questionnaire (Appendix B) which asked the recipient to identify the top three reasons why they were currently teaching or the top three reasons why they were not teaching was mailed during phase one of the study on February 1, 2002. A self-addressed, stamped envelope was included for ease and to facilitate a quicker reply. A post-card (Appendix C) was sent on February 14, 2002 to remind individuals that their replies had not been received. Responses from phase one were sorted, tabulated, and condensed into modified statements for use in phase two of the survey. Special care was given to keep the original meaning of the responses intact with the modified statements.

Phase two of the study consisted of a questionnaire developed from modified statements from the phase one responses and ten additional questions that focused on the demographics of the respondent. An instructional letter (Appendix D), signed by the researcher and the faculty advisor, along with the phase two questionnaire (Appendix E) and a self-addressed, stamped envelope were mailed during phase two of the study on March 7, 2002. A reminder post-card (Appendix F) was sent on March 14, 2002 to remind individuals that their replies had not been received.

Individuals participating in the study were assured that their participation in the study and their responses would remain as confidential as possible. To insure this confidentiality, no names were used on the questionnaire and numbers were used to code responses and monitor non-response. April 10, 2002 was established as the last day responses from the population would be included in this study. 


\section{Response}

The population of this study was the individuals who graduated between 1998-2001 and who are certified pre-service agricultural education teachers from the Five Star Consortium. The target population was determined to be 75 pre-service agricultural education teachers. From this population, two mailed questionnaires were returned as undeliverable, resulting in an accessible population of 73 . Of these 73 pre-service agricultural education teachers, $32(43.84 \%)$ returned questionnaires, all of which contained usable data (see Table 2). Late respondents were compared to early respondents to monitor for non-response error. No observable differences were noted by visual reviewing of the data collected by the researcher and faculty advisor. An analysis of variance was also performed on random late responses and early responses to monitor for differences. No significant differences were noted, therefore, the results of the study were assumed to be representative of the entire population.

Table 2

Questionnaire Response Rate

\begin{tabular}{ccc}
\hline Total Population & Total Accessible Population & $\begin{array}{l}\text { Returned Completed } \\
\text { Questionnaires }\end{array}$ \\
\hline $\mathrm{N}=75$ & $\mathrm{~N}=73$ & $\mathrm{~N}=32$
\end{tabular}

\section{Analysis of the Data}

Data collected for this study were analyzed at West Virginia University using the Statistical Package for Social Sciences (SPSS-PC+). Frequencies and descriptive statistics were used to describe and analyze the data. Levels of significance were set $a$ priori at $\mathrm{p}<.05$ for all statistical tests. An analysis of variance was performed on the data to test for differences between late respondents and early respondents. The teaching and non-teaching responses to 
phase one of the survey were grouped into five teaching categories and three non-teaching categories. During the data analysis process, an average was calculated using the item scores within each category. 


\section{Chapter IV}

\section{Findings}

The purpose of this study was to provide information to colleges, teacher educators, and school districts regarding common characteristics of pre-service agricultural education teachers who enter teaching and the relationship of the student teaching experience and their decision to teach.

The primary objective of this study was to determine the impact of the student teaching experience upon the decision to enter into teaching of pre-service agricultural education teachers who graduated between 1998 and 2001 in states served by the Five Star Consortium. Secondary objectives for this study were to determine the impact of the personal demographics and the impact of selected factors on the decision of the pre-service agricultural education teachers to enter into teaching. This study also attempted to identify differences in pre-service agriculture education teachers among the different institutions included in this study.

The population of this study was individuals from the Five Star Consortium who graduated between 1998-2001 and who were pre-service agricultural education teachers. The total population was determined to be 75 pre-service agricultural education teachers. The population was comprised of four individuals from Delaware Valley College (DVC), 37 individuals from Pennsylvania State University (PSU), and 34 individuals from West Virginia University (WVU). Two questionnaires were returned as undeliverable. Of the remaining 73 questionnaires, 32 (43.84\%) were returned, all of which contained usable data.

\section{Distribution of Respondents by Institution}

The 32 respondents to the questionnaire represented three different institutions of higher education in two states. The respondents included two from Delaware Valley College (6.3\%), 
13 from Pennsylvania State University (40.6\%), and 17 individuals from West Virginia University $(53.1 \%)$ (see Figure 1).

Figure 1. Distribution of respondents by institution

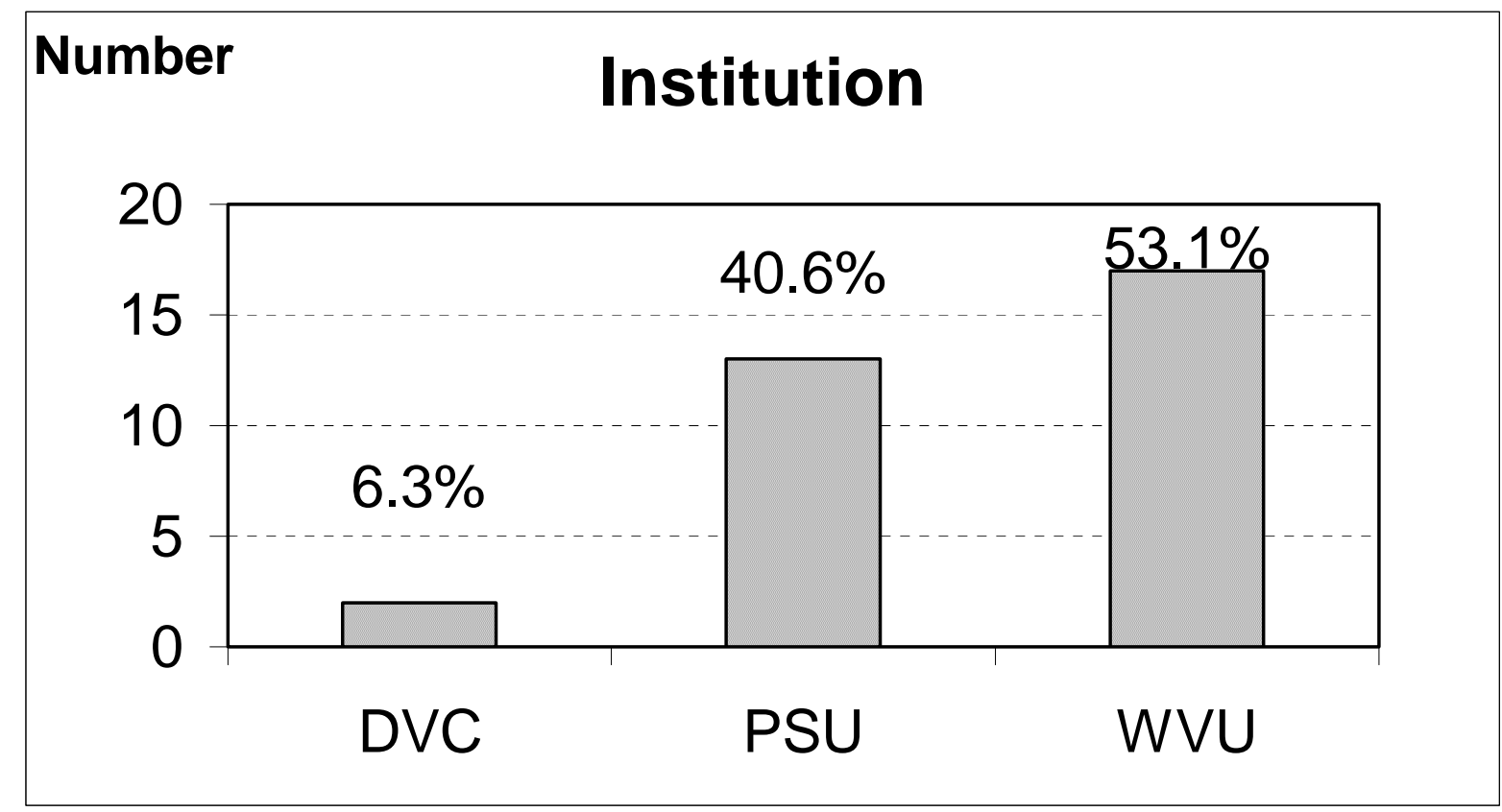

\section{Demographic Characteristics}

Participants were asked to identify their gender. Twenty-two of the respondents were female $(68.8 \%)$, while ten were male (31.2\%). Of the ten male respondents, one (10.0\%) was from Delaware Valley College, five (50.0\%) were from Pennsylvania State University, and four (40.0\%) were from West Virginia University. Of the 22 female respondents, one (4.5\%) was from Delaware Valley College, eight (36.4\%) were from Pennsylvania State University, and thirteen (59.1\%) were from West Virginia University (see Figure 2). 
Figure 2. Distribution of respondents by gender

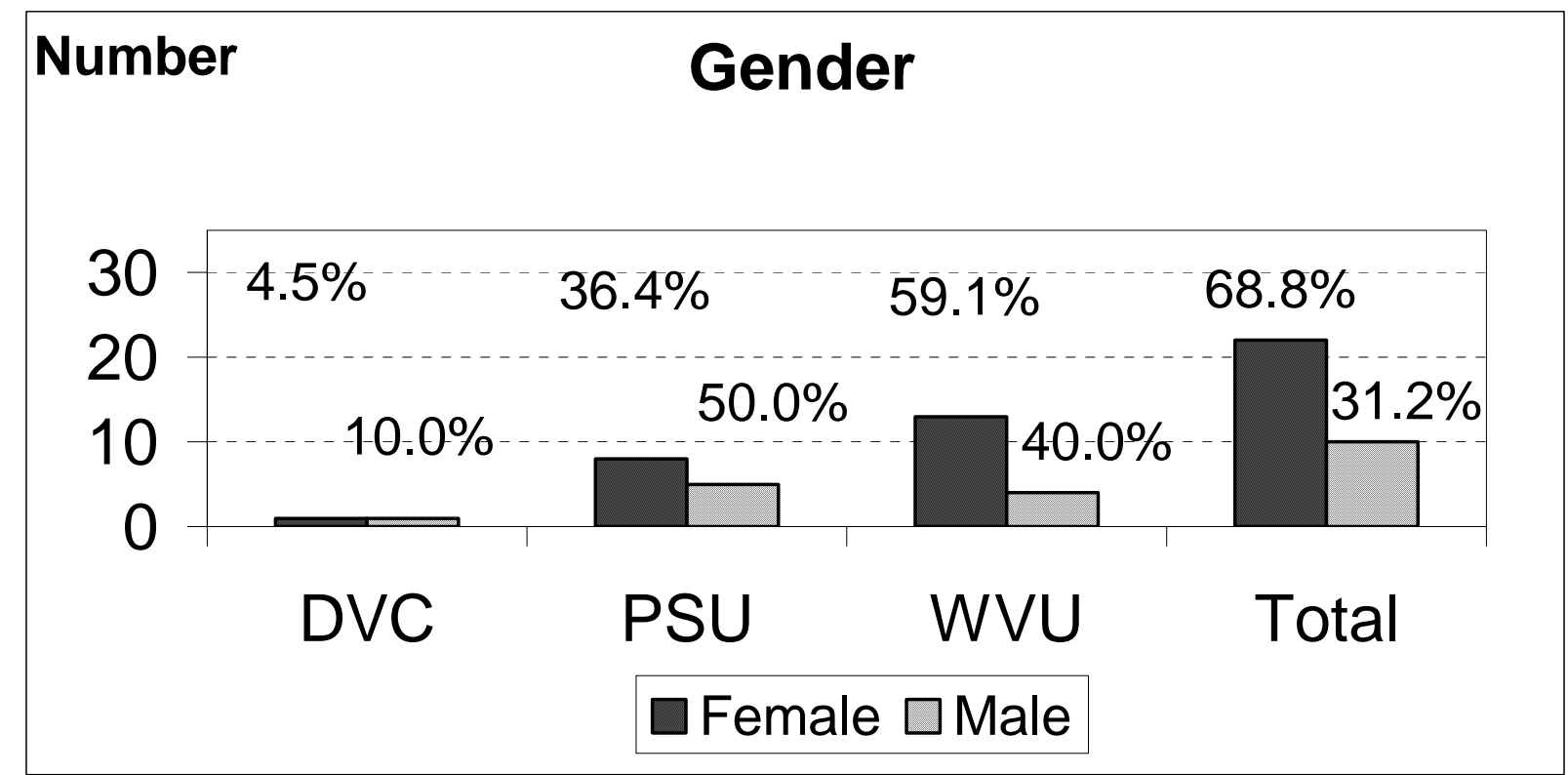

Participants were asked to identify their age. The minimum age (see Figure 3 ) for respondents was $22(15.6 \%)$ while the maximum was forty $(3.1 \%)$. The average age (see Table 3) was 24.47 years.

Figure 3. Distribution of respondents' age

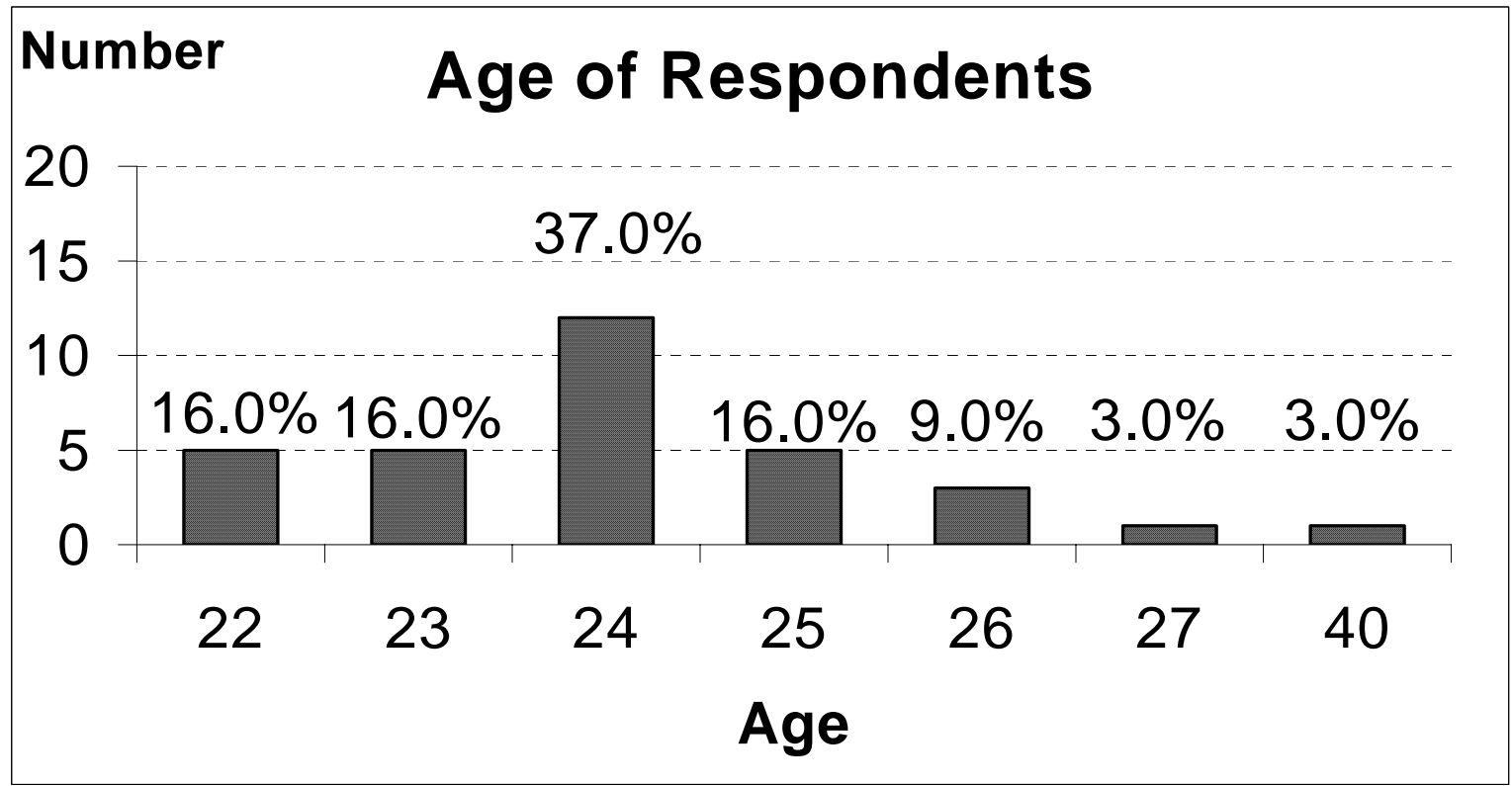


Table 3

Age of Respondents

\begin{tabular}{lcrrr}
\hline & $X$ & \multicolumn{1}{c}{$S D$} & Min & Max \\
\hline DVC & 31.50 & 12.02 & 23 & 40 \\
PSU & 24.00 & 1.00 & 22 & 26 \\
WVU & 24.00 & 1.54 & 22 & 27 \\
Total & 24.47 & 3.11 & 22 & 40 \\
\hline
\end{tabular}

Participants were asked to provide an age when they decided they wanted to teach agricultural education. Minimum age of decision for the respondents was sixteen (5.9\%) while the maximum age of decision was $23(11.8 \%)$. The mean age of decision to teach was 19.94 years(see Figure 4) (see Table 4).

Figure 4. Distribution of age of decision of respondents to teach

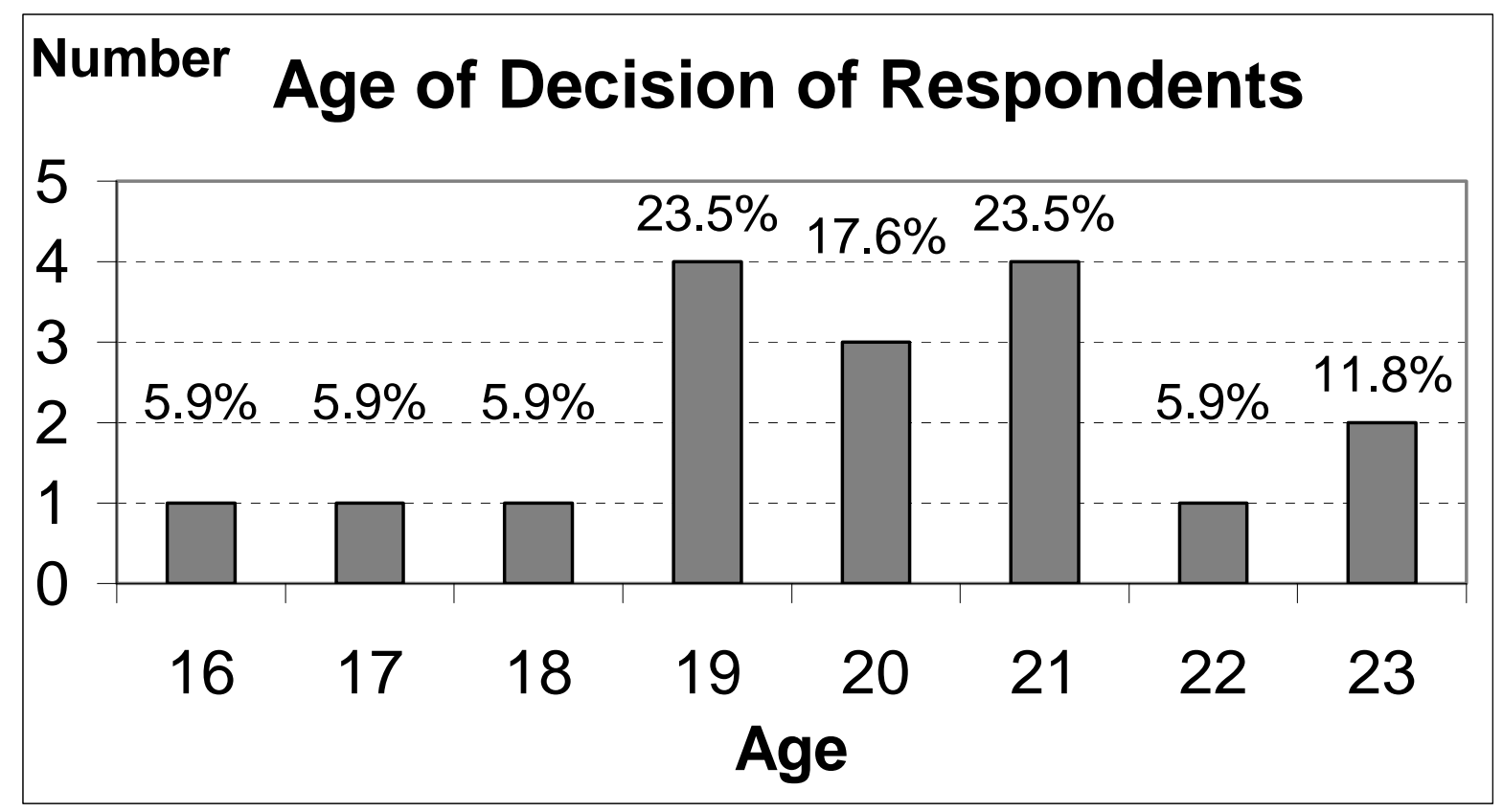


Table 4

Age of Decision of Respondents to Teach

\begin{tabular}{lcccc}
\hline & $X$ & $S D$ & Min & Max \\
\hline DVC & N/A & N/A & N/A & N/A \\
PSU & 19.45 & 1.63 & 16 & 22 \\
WVU & 20.83 & 2.23 & 17 & 23 \\
Total & 19.94 & 1.92 & 16 & 23 \\
\hline
\end{tabular}

Participants were asked to identify/classify the area in which they spent their childhood. Twenty-five (78.1\%) were from a rural area, six (18.8\%) were from an urban area and one (3.1\%) respondent was from a combination of both areas. Of the 25 respondents from a rural area, two (8.0\%) were from Delaware Valley College, ten (40.0\%) were from Pennsylvania State University, and thirteen $(52.0 \%)$ were from West Virginia University. Of the six respondents from an urban area, three $(50.0 \%)$ were from Pennsylvania State University and three (50.0\%) were from West Virginia University. The one respondent who was from both the rural and urban area was from West Virginia University (see Figure 5). 
Figure 5. Distribution of respondents by upbringing

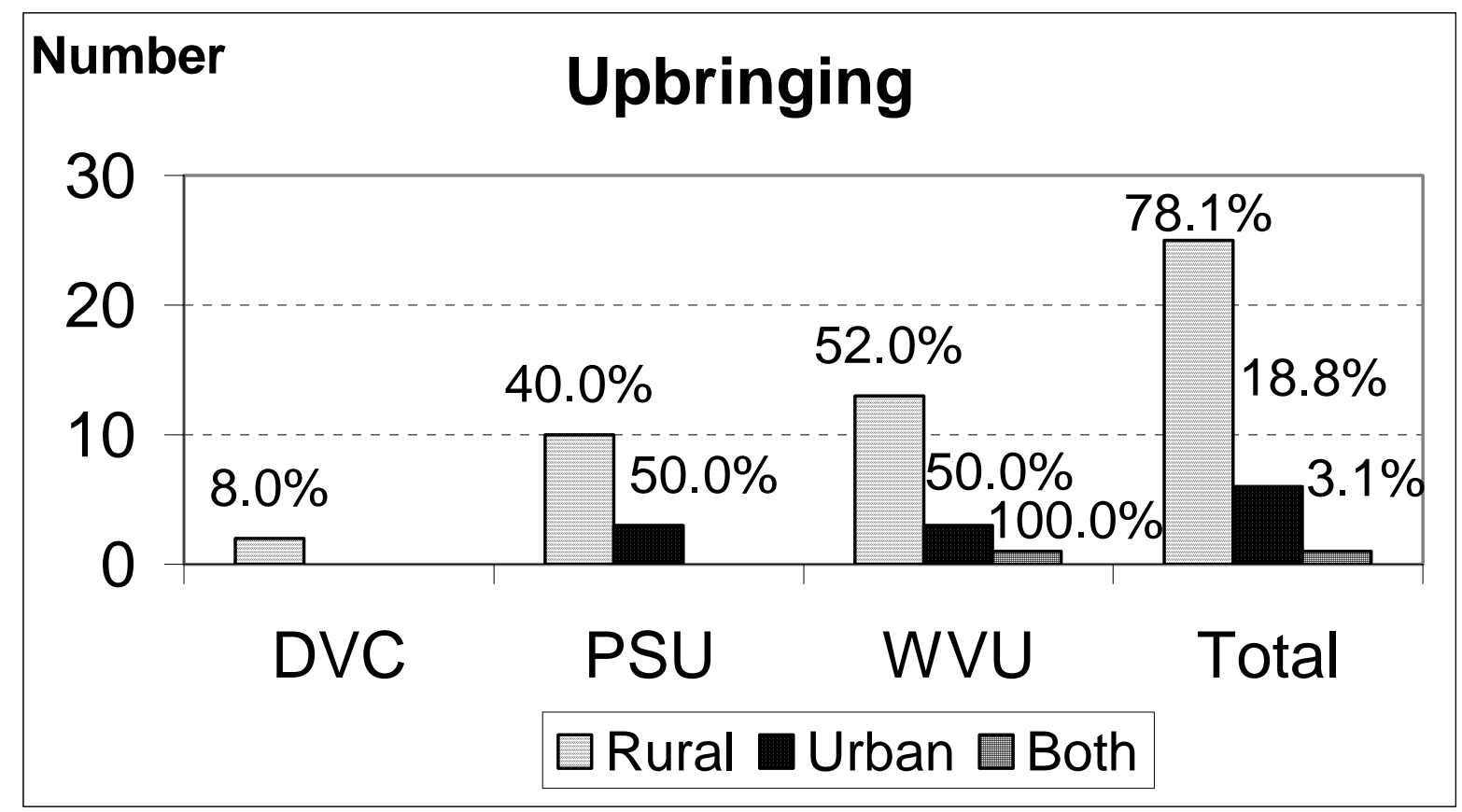

\section{Distribution of Respondents by Teaching Status}

Participants were asked if they were currently teaching agricultural education. Responses to the question were grouped into two different categories, teaching and non-teaching. Sixteen $(50.0 \%)$ of the respondents were teaching while sixteen $(50.0 \%)$ of the respondents were not teaching. Of the sixteen respondents who were teaching, eleven $(69.0 \%)$ were from Pennsylvania State University and five (31.0\%) were from West Virginia University. Of the sixteen who were not teaching, two (12.5\%) were from Delaware Valley College, two (12.5\%) were from Pennsylvania State University, and twelve (75.0\%) were from West Virginia University (see Figure 6).

Of the sixteen respondents that were teaching, six (37.5\%) were male and ten $(62.5 \%)$ were female. Of the sixteen respondents that were not teaching, four (25.0\%) were male and twelve $(75.0 \%)$ were female. Of the sixteen respondents that were teaching, $12(75.0 \%)$ were 
from a rural upbringing and four $(25.0 \%)$ were from an urban upbringing. Of the sixteen respondents that were not teaching, $13(81.3 \%)$ were from a rural upbringing, two $(12.5 \%)$ were from an urban upbringing, and one (6.2\%) was from both a rural and an urban upbringing (see Figure 8). Of the sixteen respondents that were teaching, two (12.5\%) were not enrolled in any agricultural classes in high school while $14(87.5 \%)$ were enrolled in four years of agricultural classes in high school. Of the sixteen respondents that were not teaching, five (31.3\%) of the respondents were not enrolled in any agricultural classes in high school, one (6.3\%) was enrolled in one year of agricultural classes in high school, one (6.3\%) was enrolled in two years of agricultural classes in high school, and nine (56.1\%) of the respondents were enrolled in four years of agricultural classes in high school (see Figure 9).

Figure 6. Distribution of respondents by teaching status

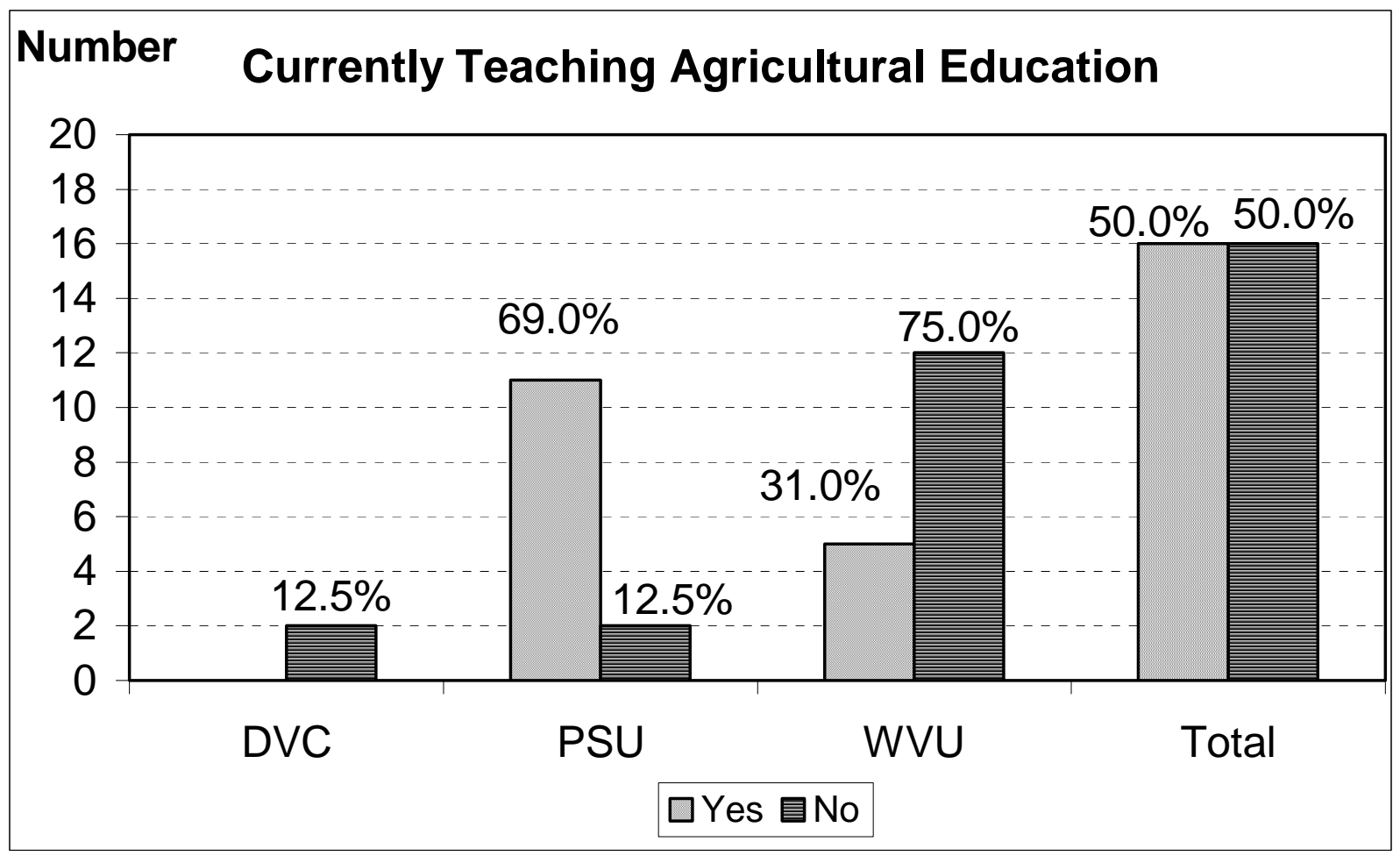


Figure 7. Distribution of respondents by teaching status and gender

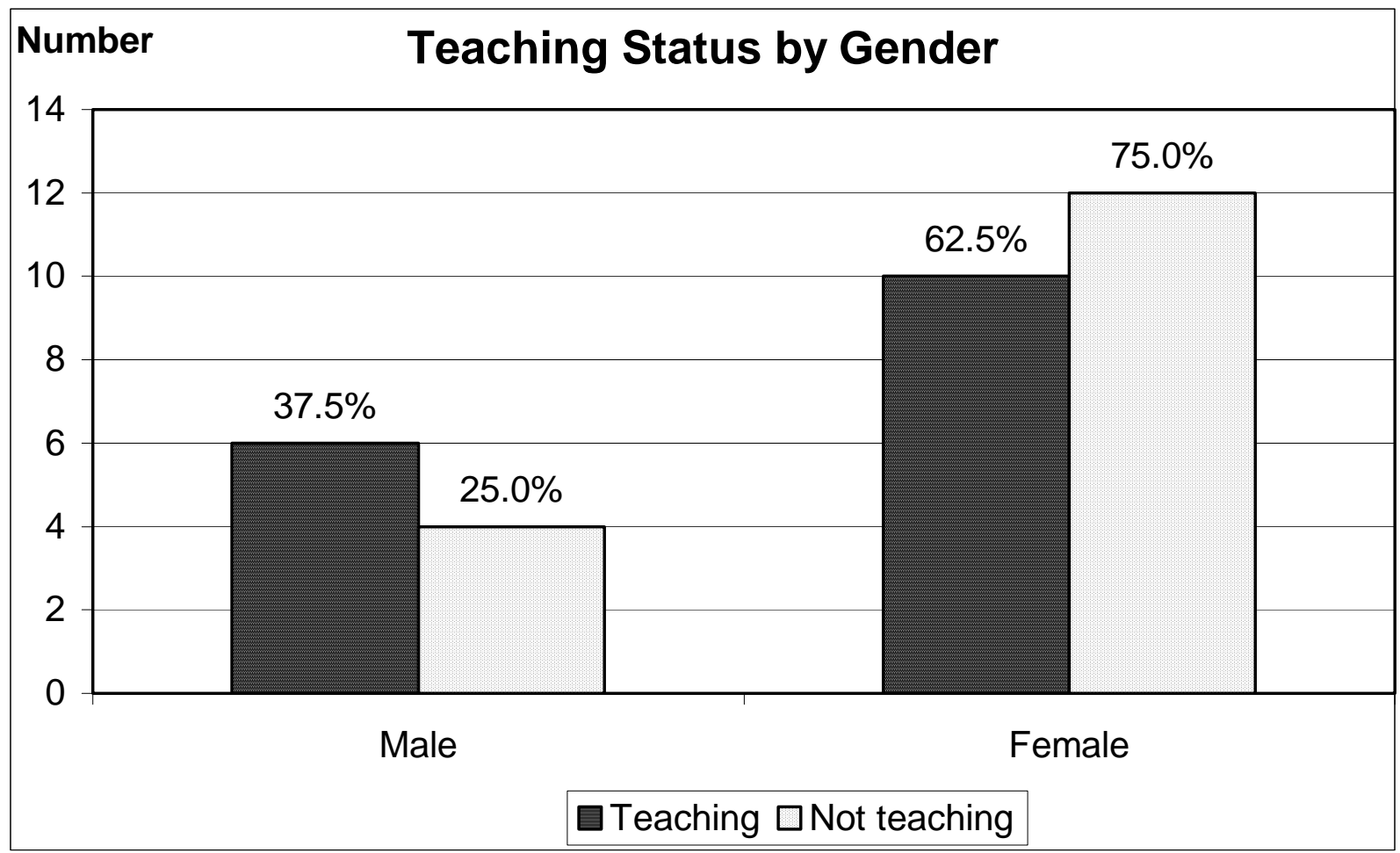

Figure 8. Distribution of respondents by teaching status and upbringing

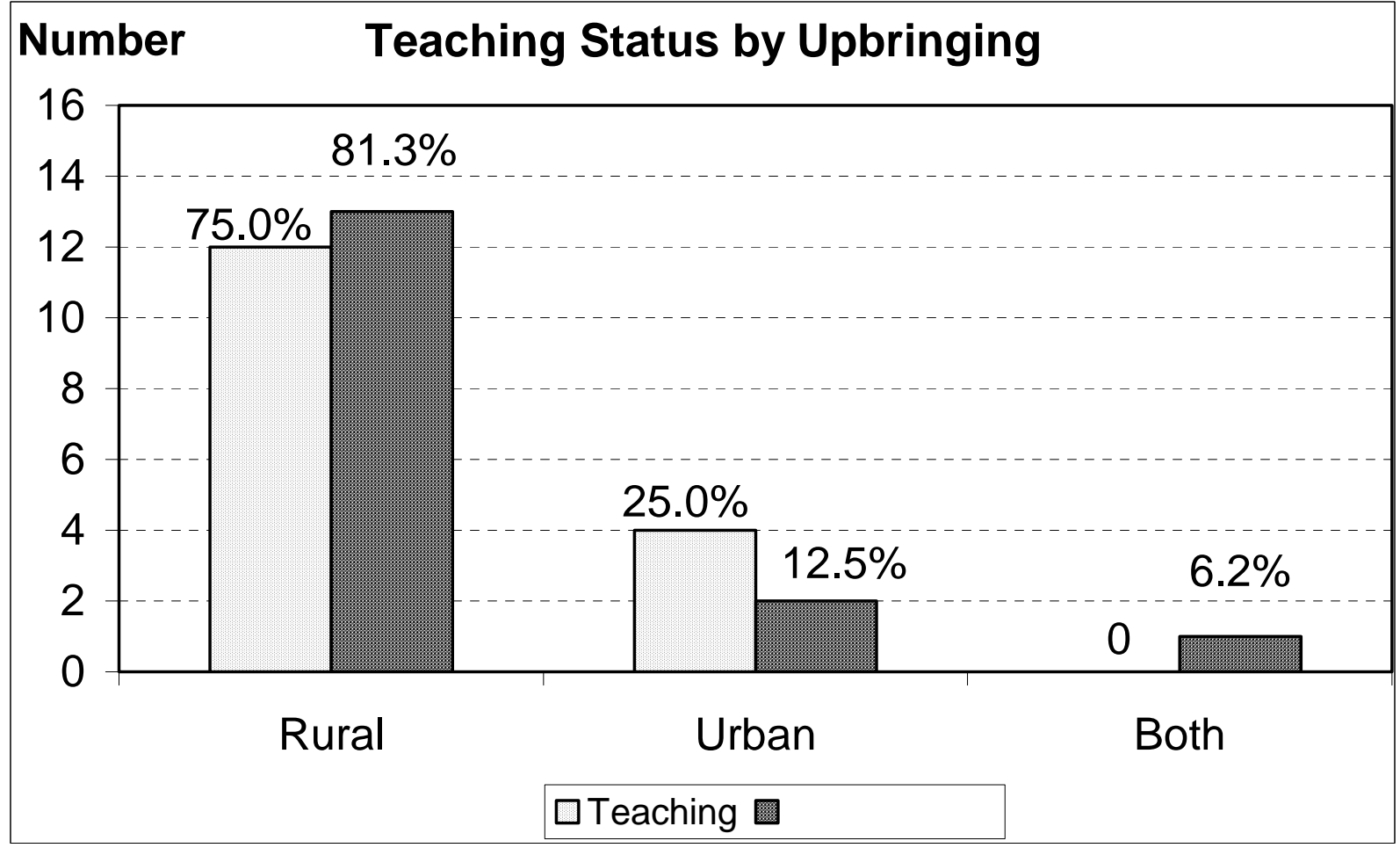


Figure 9. Distribution of respondents by teaching status and average number of years in agricultural classes

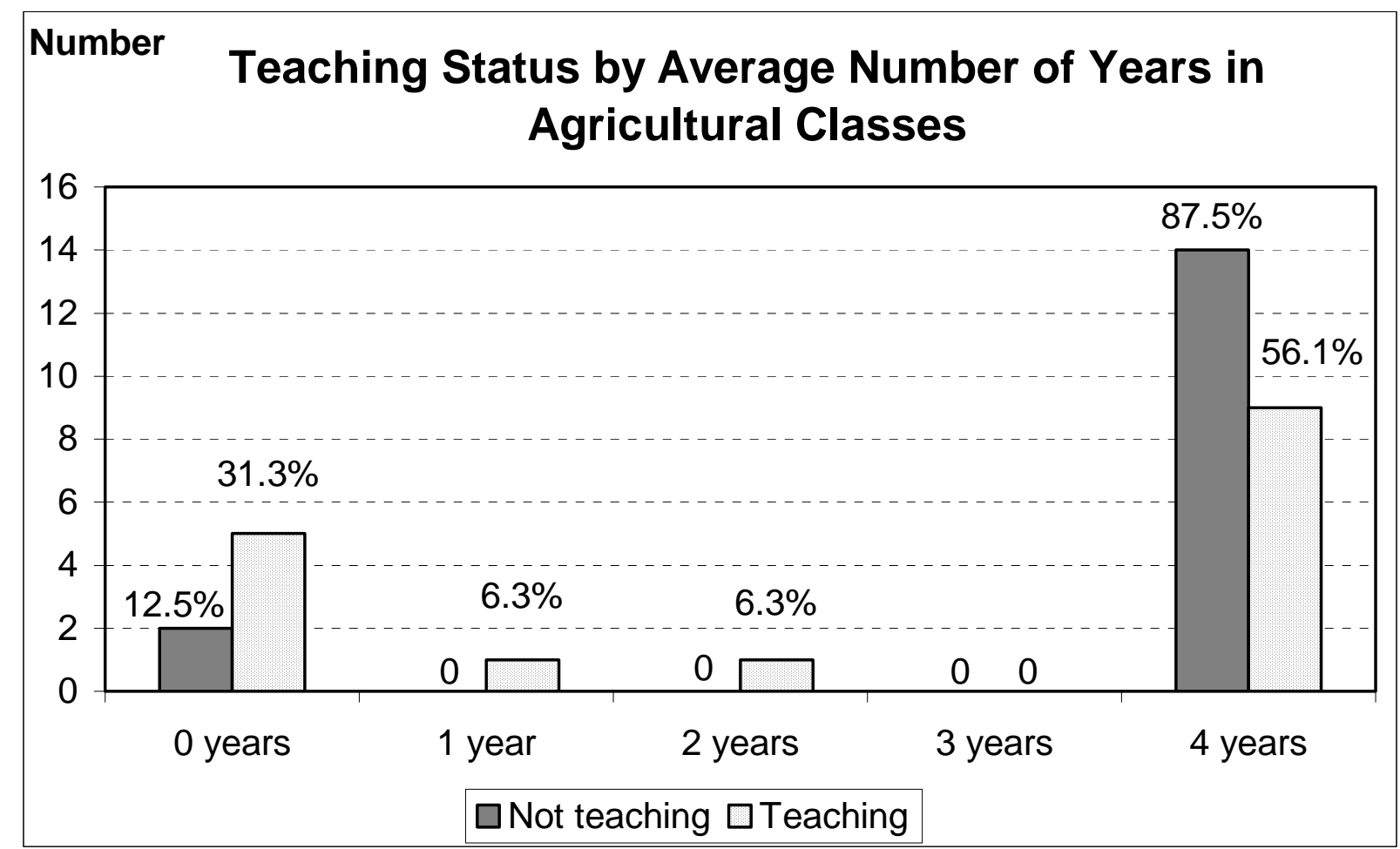

\section{FFA Membership in High School}

Participants were asked if they had been a member of the FFA during high school.

Twenty-five respondents $(78.1 \%)$ indicated they had been members of the FFA in high school whereas seven respondents $(21.9 \%)$ noted that they had not. The twenty-five respondents that had been members of the FFA were comprised of two (8.0\%) from Delaware Valley College, eight (32.0\%) from Pennsylvania State University, and fifteen (60.0\%) from West Virginia University. Of the seven respondents that had not been members of the FFA, five (71.4\%) from Pennsylvania State University and two (28.6\%) from West Virginia University (see Figure 10). 
Figure 10. Distribution of respondents by FFA membership

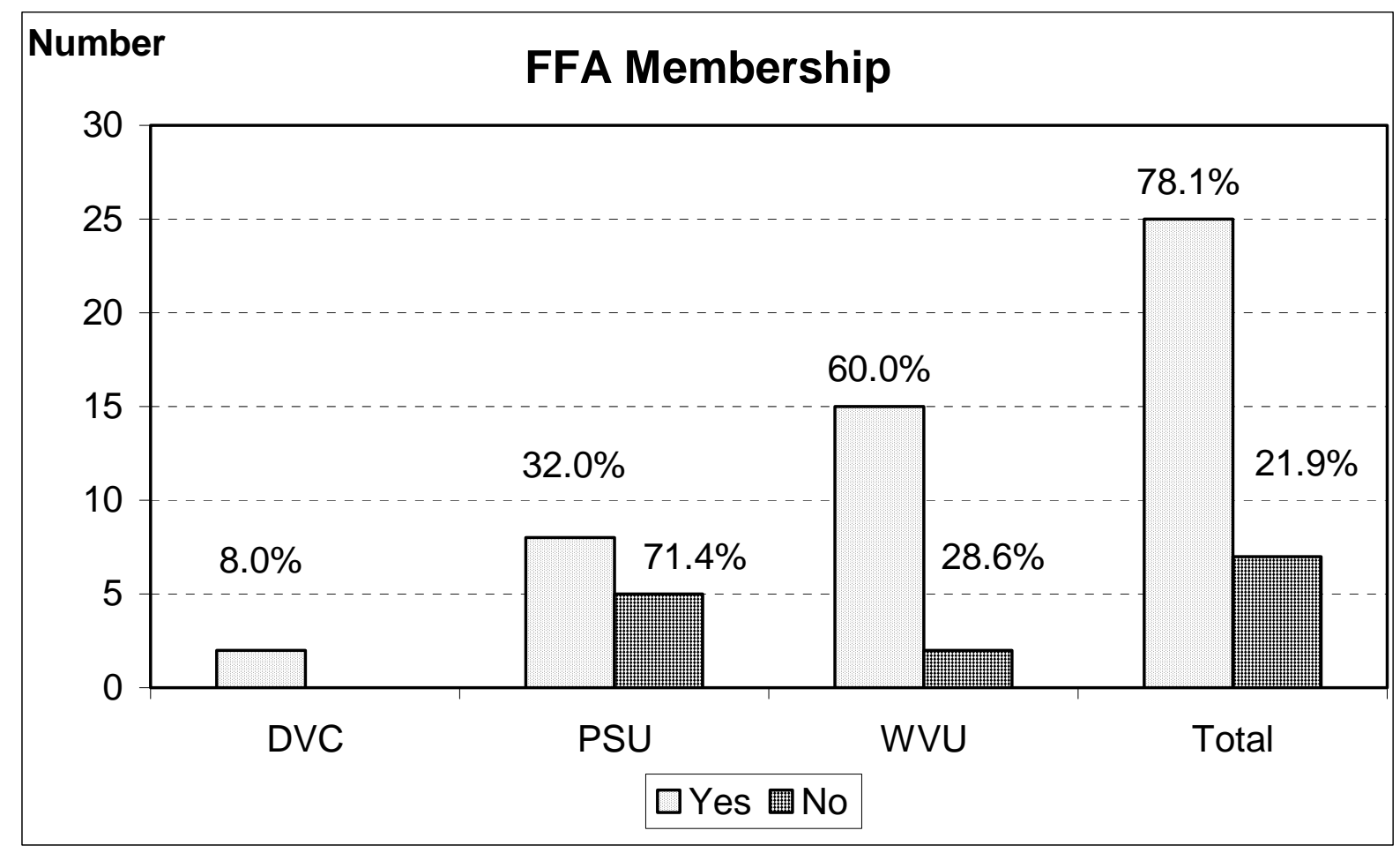

Student Organization Membership in College

Participants were asked if they had been a member of a student organization in college.

Twenty-eight respondents (87.5\%) indicated they had been members of one or more student organizations in college while four respondents $(12.5 \%)$ noted that they had not. Of the twentyeight respondents who had been members of some student organization in college, two (7.1\%) were from Delaware Valley College, ten (35.8\%) were from Pennsylvania State University, and sixteen $(57.1 \%)$ were from West Virginia University. Of the four respondents who had not been members of some student organization in college, three (75.0\%) were from Pennsylvania State University and one (25.0\%) was from West Virginia University (see Figure 11). 
Figure 11. Distribution of respondents by college organization membership

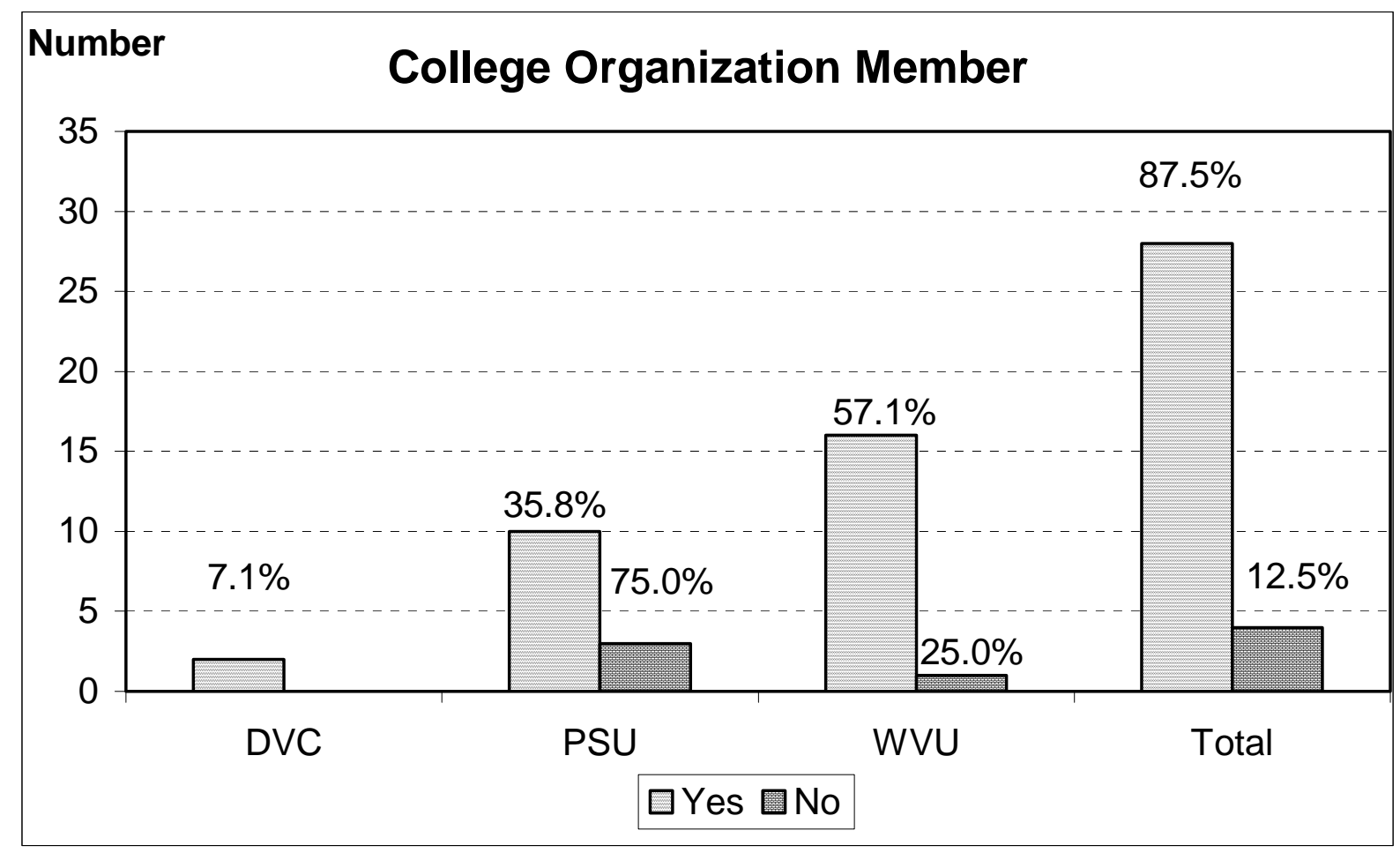

Relationships with Supervising and Cooperating Teachers

Participants were asked to characterize their relationship with their cooperating teacher. One respondent $(3.1 \%)$ replied that he/she did not have a positive relationship with their cooperating teacher during student teaching. Thirty-one of the 32 respondents replied that they had a positive relationship with their cooperating teacher during student teaching. The one respondent who did not have a positive relationship with their cooperating teacher during student teaching was from Pennsylvania State University. The thirty-one respondents who replied that they did have a positive relationship with their cooperating teacher during student teaching, three (9.7\%) were from Delaware Valley College, eleven (35.5\%) were from Pennsylvania State University, and seventeen (54.8\%) were from West Virginia University (see Figure 12). 
Figure 12. Distribution of respondents by positive cooperating teacher relationship

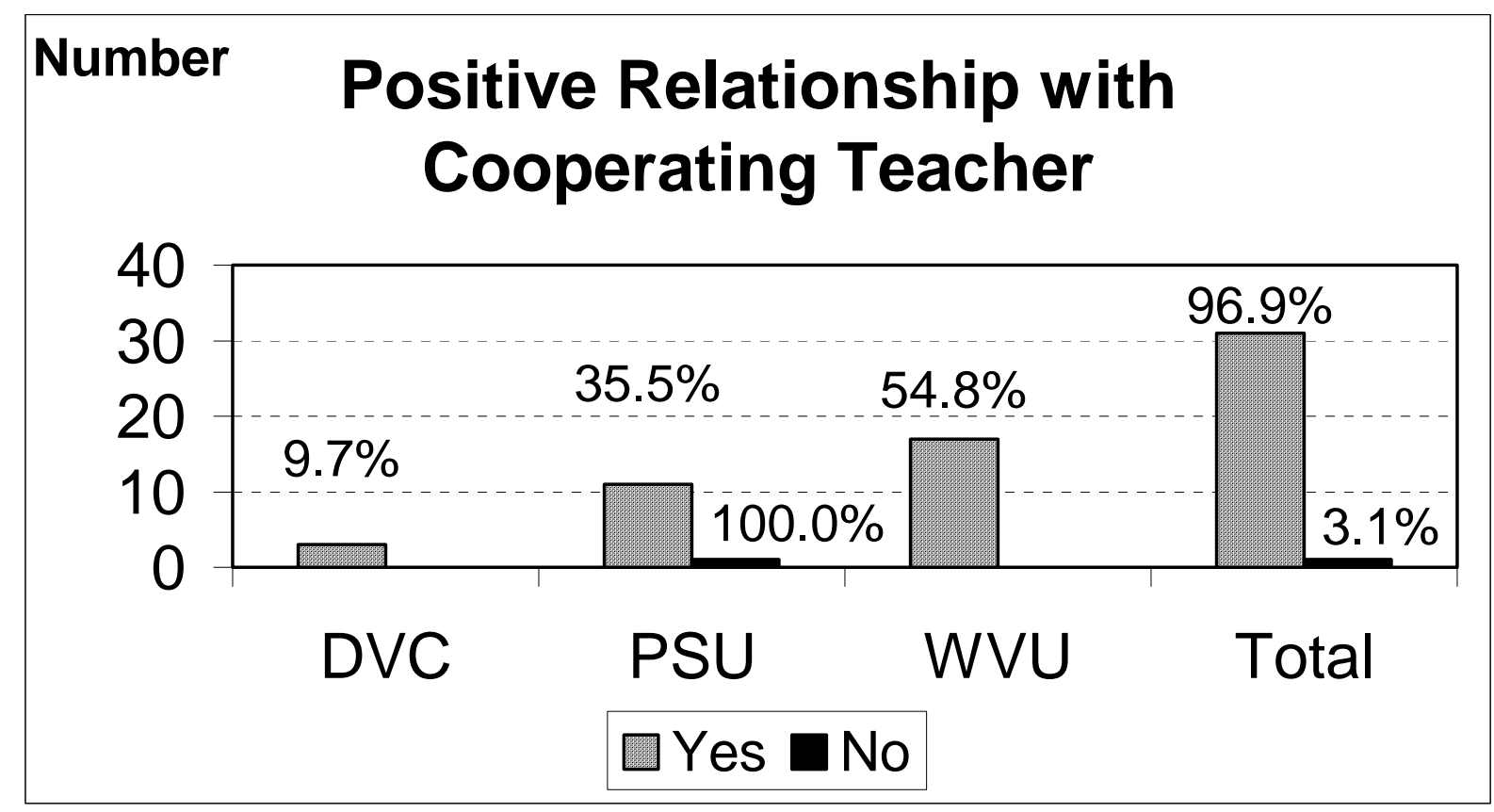

Participants were also asked to characterize their relationship with their university supervisor. Two respondents (6.3\%) replied that they did not have a positive relationship with their university supervisor during student teaching. Thirty of the 32 respondents replied they had a positive relationship with their university supervisor during student teaching. Of the two respondents who did not have a positive relationship with their university supervisor during student teaching, one (50.0\%) was from Delaware Valley College and one (50.0\%) was from West Virginia University. Of the thirty-one respondents who replied that they did have a positive relationship with their university supervisor during student teaching, one (3.3\%) was from Delaware Valley College, thirteen (43.3\%) were from Pennsylvania State University, and sixteen (53.4\%) were from West Virginia University (see Figure 13). 
Figure 13. Distributions of respondents by positive university supervisor relationship

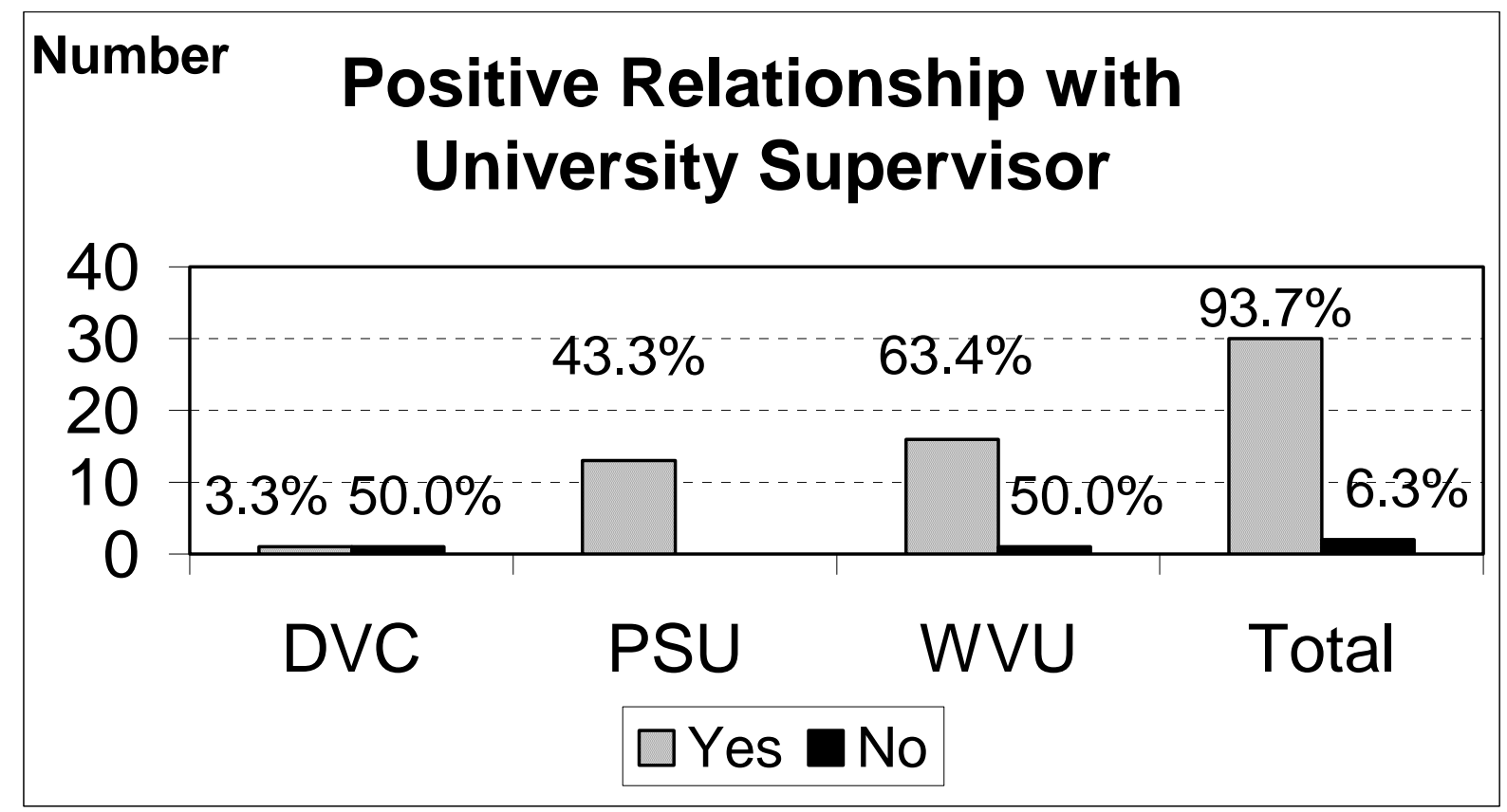

Number of Years in Agricultural Classes

Participants were asked to indicate the number of years that they had been enrolled in agricultural classes in high school. The minimum number of years was zero $(22.0 \%)$ while the maximum number of years was four $(69.0 \%)$. The mean number of years in agricultural classes for the respondents was 2.95 years (see Table 5) (see Figure 14) (see Figure 15).

Table 5

Number of Years in Agricultural Classes

\begin{tabular}{llrrc}
\hline & $X$ & \multicolumn{1}{c}{$S D$} & Min & Max \\
\hline DVC & 4.00 & .00 & 4 & 4 \\
PSU & 2.19 & 2.04 & 0 & 4 \\
WVU & 3.41 & 1.37 & 0 & 4 \\
Total & 2.95 & 1.73 & 0 & 4 \\
\hline
\end{tabular}


Figure 14. Distribution of respondents by years in agricultural classes and by institution

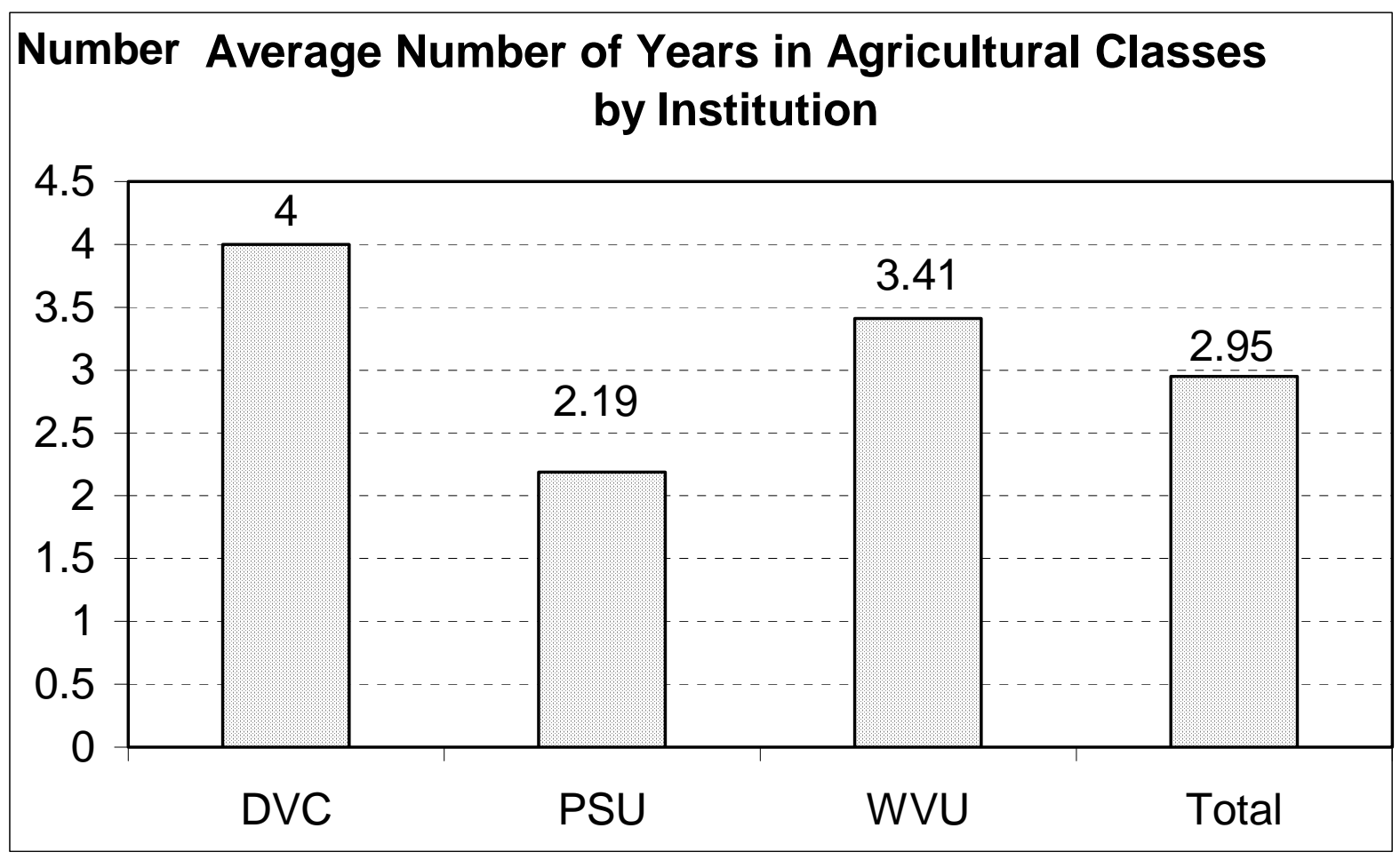

Figure 15. Distribution of respondents by number of years in agricultural classes

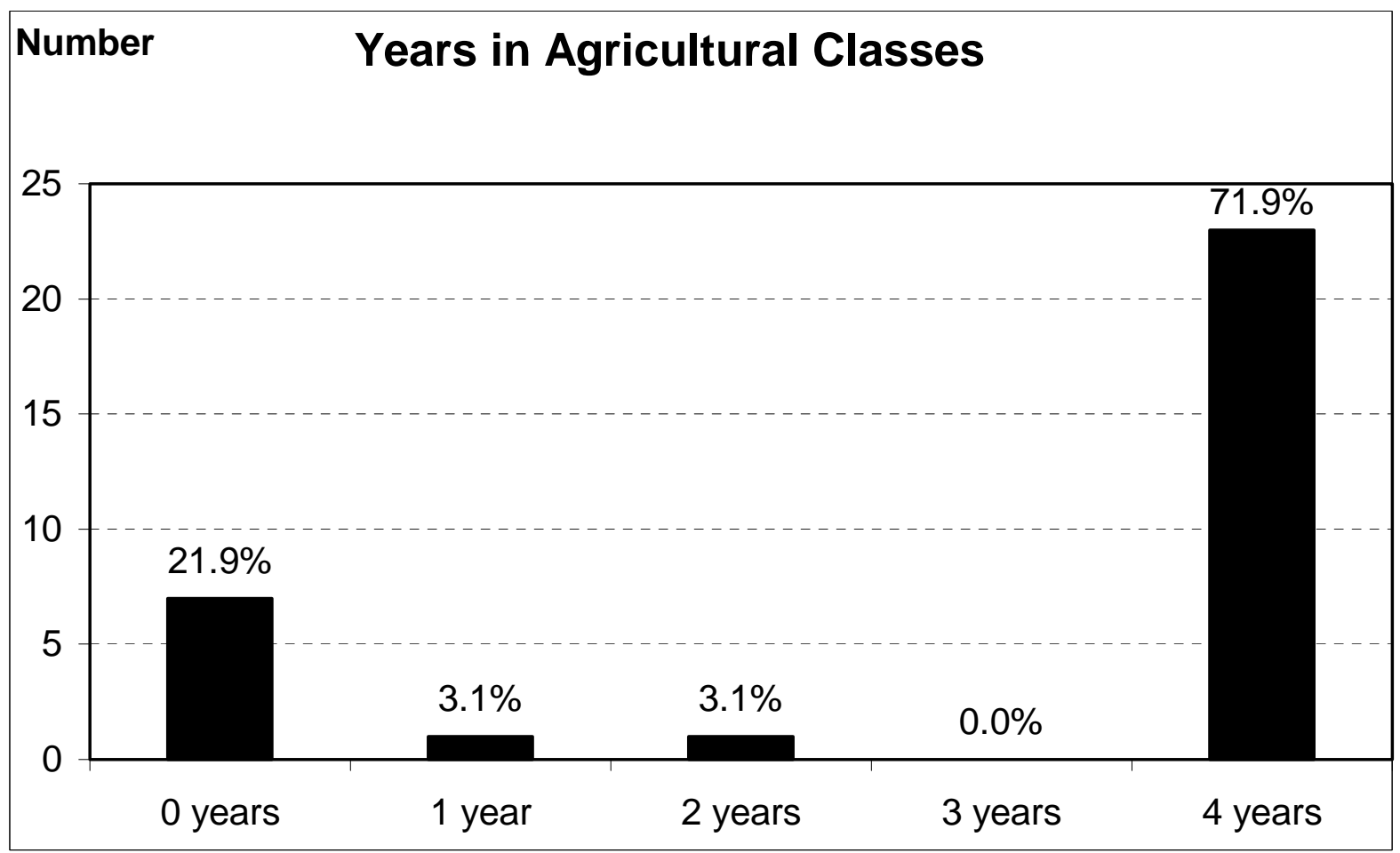




\section{Responses to Teaching Categories}

Respondents, who were teaching agricultural education, were asked to rank 24 statements on a scale of 1 to 5 with 1 being strongly disagree, 2 being disagree, 3 being neutral, 4 being agree, and 5 being strongly agree with respect to how much of an impact the factors in the statements helped them decide to teach. The statements were divided into five categories of teaching including: influences, location, benefits, characteristics, and personal. A complete distribution of the responses by each statement in the questionnaire can be found in Appendix G.

\section{$\underline{\text { Influences category }}$}

The teaching influences category received the lowest rating from the respondents. Statements within the teaching influences category were: influenced by other teachers, influenced by high school agriculture teacher, influenced by family, influenced by friends, and an enjoyable student teaching experience. Of the 16 respondents, seven (43.8\%) agreed that teaching influences had an impact on their decision to teach, seven (43.8\%) were neutral that teaching influences had an impact on their decision to teach, one $(6.3 \%)$ disagreed that teaching influences had an impact on their decision to teach, and one (6.3\%) strongly disagreed that teaching influences had an impact on their decision to teach (see Table 6). The average response to the teaching influences category was 3.34. Average response from Pennsylvania State University was 3.44 and average response from West Virginia University was 3.17 (see Table 7) (see Table 8). Distribution of the responses within the teaching influences category can be found in Appendix $\mathrm{H}$.

\section{Location category}

The teaching location category was the third highest valued category from the respondents. Statements within the teaching location category were: live in home community 
and make a difference in community. Of the 17 respondents to the teaching location category, one $(5.9 \%)$ strongly agreed that teaching location had an impact on their decision to teach, eight (47.1\%) agreed that teaching location had an impact on their decision to teach, five $(29.4 \%)$ were neutral that teaching location had an impact on their decision to teach, and three $(17.6 \%)$ disagreed that teaching location had an impact on their decision to teach (see Table 6). The mean response to the teaching location category was 3.65. Average response from Pennsylvania State University was 3.77 and average response from West Virginia University was 3.42 (see Table 7) (see Table 8). Distribution of the responses within the teaching location category can be found in Appendix I.

$\underline{\text { Benefits category }}$

The teaching benefits category was the next to the lowest rated category from the respondents. Statements within the teaching benefits category were: career offers good benefits, career offers insurance protection, career offers good work hours, and career provides vacation time. Of the 17 respondents to the teaching benefits category, one (5.9\%) strongly agreed that teaching benefits had an impact on his/her decision to teach, six (35.3\%) agreed that teaching benefits had an impact on their decision to teach, nine (52.9\%) were neutral that teaching benefits had an impact on their decision to teach, and one (5.9\%) disagreed that teaching benefits had an impact on their decision to teach (see Table 6). The average response to the teaching benefits category was 3.65. Average response from Pennsylvania State University was 3.49 and average response from West Virginia University was 3.58 (see Table 7) (see Table 8).

Distribution of the responses within the teaching benefits category can be found in Appendix J. 


\section{Characteristics category}

The teaching characteristics category received the highest ratings from the respondents. Statements within the teaching characteristics category were: love to interact with people, love to work with students, teach life skills to students, and teach proper stewardship. Of the 17 respondents to the teaching characteristics category, seven (41.2\%) strongly agreed and 10 (58.8\%) agreed that teaching characteristics had an impact on their decision to teach (see Table 6). The average response to the teaching characteristics category was 4.53. Average response from Pennsylvania State University was 4.54 and average response from West Virginia University was 4.53 (see Table 7) (see Table 8). Distribution of the responses within the teaching characteristics category can be found in Appendix K.

Personal category

The teaching personal category received the second highest ratings from the respondents. Statements within the teaching personal category were: make a difference in students' lives, positive influence on students, enjoy teaching, have fun teaching, have the ability to pass on knowledge, teaching came naturally, teaching was my career dream, and always had desire to teach. From the 17 respondents to the teaching personal category, two (11.8\%) strongly agreed that the teaching personal category had an impact on their decision to teach, $13(76.5 \%)$ agreed that the teaching personal category had an impact on their decision to teach and two (11.8\%) were neutral that the teaching personal category had an impact on their decision to teach (see Table 6). The average response to the teaching personal category was 3.99. Average response from Pennsylvania State University was 4.02 and average response from West Virginia University was 3.93 (see Table 7) (see Table 8). Distribution of the responses within the teaching personal category can be found in Appendix L. 
Table 6

Distribution of Respondents to the Different Teaching Categories

\begin{tabular}{|c|c|c|c|c|c|c|c|c|c|c|}
\hline & \multicolumn{2}{|c|}{$\begin{array}{l}\text { Teaching - } \\
\text { Influences }\end{array}$} & \multicolumn{2}{|c|}{$\begin{array}{l}\text { Teaching - } \\
\text { Location }\end{array}$} & \multicolumn{2}{|c|}{$\begin{array}{l}\text { Teaching - } \\
\text { Benefits }\end{array}$} & \multicolumn{2}{|c|}{$\begin{array}{l}\text { Teaching - } \\
\text { Characteristics }\end{array}$} & \multicolumn{2}{|c|}{$\begin{array}{l}\text { Teaching - } \\
\text { Personal }\end{array}$} \\
\hline & $N$ & $\%$ & $N$ & $\%$ & $N$ & $\%$ & $N$ & $\%$ & $N$ & $\%$ \\
\hline Strongly Disagree & 1 & 6.3 & & & & & & & & \\
\hline Disagree & 1 & 6.3 & 3 & 17.6 & 1 & 5.9 & & & & \\
\hline Neutral & 7 & 43.8 & 5 & 29.4 & 9 & 52.9 & & & 2 & 11.8 \\
\hline Agree & 7 & 43.8 & 8 & 47.1 & 6 & 35.3 & 10 & 58.8 & 13 & 76.5 \\
\hline Strongly Agree & & & 1 & 5.9 & 1 & 5.9 & 7 & 41.2 & 2 & 11.8 \\
\hline
\end{tabular}

Table 7

Distribution of Respondents to the Different Teaching Categories by Institution

\begin{tabular}{lccc}
\hline & $\begin{array}{c}\text { Penn State } \\
\text { University }\end{array}$ & $\begin{array}{c}\text { West Virginia } \\
\text { University }\end{array}$ & Overall \\
\hline Teaching - Characteristics & $X$ & $X$ & \\
Teaching - Personal & 4.53 & 4.54 & 4.53 \\
Teaching - Location & 4.02 & 3.93 & 3.99 \\
Teaching - Benefits & 3.77 & 3.42 & 3.65 \\
Teaching - Influences & 3.49 & 3.58 & 3.52 \\
\hline
\end{tabular}

Rating scale: $1=$ strongly disagree to $5=$ strongly agree 
Table 8

Distribution of Respondents to the Different Teaching Categories by Institution

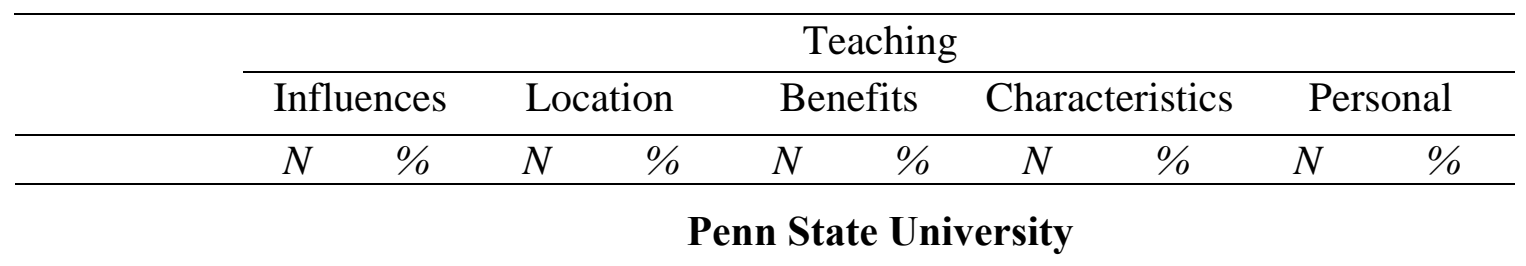

Strongly

\begin{tabular}{lrrrrrrrrrr} 
Disagree & 0 & 0.0 & 0 & 0.0 & 0 & 0.0 & 0 & 0.0 & 0 & 0.0 \\
Disagree & 1 & 9.1 & 2 & 18.2 & 1 & 9.1 & 0 & 0.0 & 0 & 0.0 \\
Neutral & 4 & 36.4 & 3 & 27.3 & 6 & 54.5 & 0 & 0.0 & 1 & 9.1 \\
Agree & 6 & 54.5 & 5 & 45.5 & 3 & 27.3 & 6 & 54.5 & 8 & 72.7 \\
$\begin{array}{l}\text { Strongly } \\
\text { Agree }\end{array}$ & 0 & 0.0 & 1 & 9.1 & 1 & 9.1 & 5 & 45.5 & 2 & 18.2 \\
& & \multicolumn{8}{c}{ West Virginia University }
\end{tabular}

Strongly

Disagree

$\begin{array}{llllllllll}1 & 20.0 & 0 & 0.0 & 0 & 0.0 & 0 & 0.0 & 0 & 0.0\end{array}$

$\begin{array}{lllllllllll}\text { Disagree } & 0 & 0.0 & 1 & 16.7 & 0 & 0.0 & 0 & 0.0 & 0 & 0.0\end{array}$

$\begin{array}{lllllllllll}\text { Neutral } & 3 & 60.0 & 2 & 33.3 & 3 & 50.0 & 0 & 0.0 & 1 & 16.7\end{array}$

$\begin{array}{lllllllllll}\text { Agree } & 1 & 20.0 & 3 & 50.0 & 3 & 50.0 & 4 & 66.7 & 5 & 83.3\end{array}$

Strongly

\begin{tabular}{lllllllllll} 
Agree & 0 & 0.0 & 0 & 0.0 & 0 & 0.0 & 2 & 33.3 & 0 & 0.0 \\
\hline
\end{tabular}

Responses to Non-Teaching Categories

Respondents, who were not teaching agricultural education, were asked to rank 25 statements on a scale of 1 to 5 with 1 being strongly disagree, 2 being disagree, 3 being neutral, 4 being agree, and 5 being strongly agree of how much of an impact the factors in the statements helped them decide not to teach. The 25 items were summarized into three non-teaching 
categories: teaching, factors, and influences. Distribution of the responses by each statement can be seen in Appendix M.

\section{Teaching category}

The non-teaching teaching category had the second lowest rating from the respondents as an impact on their decision not to teach. Statements within the non-teaching teaching category were: incompetent school administrators, no administrative support, found alternate job, needed more flexible schedule, no job for spouse, not willing to move, not successful, parents questioned decisions, no support from parents, too high expectations, stress level too high, too much effort for rewards, too much state politics, lack of discipline in school system, uncaring administrators, and too many demands other than teaching. Of the 15 respondents to the non-teaching teaching category, seven $(46.7 \%)$ strongly disagreed that the non-teaching teaching category had an impact on their decision not to teach, four (26.7\%) disagreed that the non-teaching teaching category had an impact on their decision not to teach, and four $(26.7 \%)$ were neutral that the non-teaching teaching category had an impact on their decision not to teach (see Table 9). The overall mean response to the non-teaching teaching category was 1.98. Average response from Delaware Valley College was 2.73, Pennsylvania State University was 1.73 , and average response from West Virginia University was 2.62 (see Table 10) (see Table 11). Distribution of the responses within the non-teaching teaching category can be seen in Appendix N.

\section{Factors category}

The non-teaching factors category had the highest ratings from the respondents as an impact on their decision not to teach. Statements within the non-teaching factors category were: pursuing another career path, pursuing Master's degree, married, no jobs open in local area, no teaching jobs open, and looking for interesting job prospect. Of the 15 respondents to the non- 
teaching factors category, one $(6.7 \%)$ strongly disagreed that the non-teaching factors category had an impact on his/her decision not to teach, three (20.0\%) disagreed that the non-teaching factors category had an impact on their decision not to teach, ten $(66.7 \%)$ were neutral that the non-teaching factors category had an impact on their decision not to teach, and one $(6.7 \%)$ respondent agreed that that the non-teaching factors category had an impact on their decision not to teach (see Table 9). The overall mean response to the non-teaching factors category was 2.87. Average response from Delaware Valley College was 2.75, Pennsylvania State University was 2.92, and average response from West Virginia University was 2.75 (see Table 10) (see Table 11). Distribution of the responses within the non-teaching factors category can be seen in Appendix $\mathrm{O}$.

\section{$\underline{\text { Influences category }}$}

The non-teaching influences category had the lowest value from the respondents as an impact on their decision not to teach. Statements within the non-teaching influences category were: friends influenced "no" decision, family influenced "no" decision, and agriculture teacher influenced "no" decision. Of the eight respondents to the non-teaching influences category, all eight respondents disagreed that the non-teaching influences category had an impact on their decision not to teach (see Table 9). The overall mean response to the non-teaching influences category was 1.68. Average response from Delaware Valley College was 2.13, Pennsylvania State University was 1.57 , and average response from West Virginia University was 1.88 (see Table 10) (see Table 11). Distribution of the responses within the non-teaching influences category can be seen in Appendix P. 
Table 9

Distribution of Respondents to the Different Non-Teaching Categories

\begin{tabular}{|c|c|c|c|c|c|c|}
\hline & \multicolumn{2}{|c|}{$\begin{array}{l}\text { Non Teaching - } \\
\text { Teaching }\end{array}$} & \multicolumn{2}{|c|}{$\begin{array}{l}\text { Non Teaching - } \\
\text { Factors }\end{array}$} & \multicolumn{2}{|c|}{$\begin{array}{l}\text { Non Teaching - } \\
\text { Influences }\end{array}$} \\
\hline & $N$ & $\%$ & $N$ & $\%$ & $N$ & $\%$ \\
\hline Strongly Disagree & 7 & 46.7 & 1 & 6.7 & & \\
\hline Disagree & 4 & 26.7 & 3 & 20.0 & 8 & 100.0 \\
\hline Neutral & 4 & 26.7 & 10 & 66.7 & & \\
\hline Agree & & & 1 & 6.7 & & \\
\hline Strongly Agree & & & & & & \\
\hline
\end{tabular}

Table 10

Distribution of Respondents to the Different Non-Teaching Categories by Institution

\begin{tabular}{lcccc}
\hline & $\begin{array}{c}\text { West Virginia } \\
\text { University }\end{array}$ & $\begin{array}{c}\text { Delaware } \\
\text { Valley } \\
\text { College, PA }\end{array}$ & $\begin{array}{c}\text { Penn State } \\
\text { University }\end{array}$ & Total \\
\hline Non Teaching - Influences & $X$ & $X$ & $X$ & $X$ \\
Non Teaching - Teaching & 1.88 & 2.13 & 1.57 & 1.68 \\
Non Teaching - Factors & 2.62 & 2.73 & 1.73 & 1.98 \\
\hline Rating & 2.75 & 2.75 & 2.92 & 2.87 \\
\hline
\end{tabular}

Rating scale: $1=$ strongly disagree to $5=$ strongly agree 
Table 11

Distribution of Respondents to the Different Non-Teaching Categories by Institution

\begin{tabular}{|c|c|c|c|c|c|c|}
\hline & \multicolumn{6}{|c|}{ Non-Teaching } \\
\hline & \multicolumn{2}{|c|}{ Teaching } & \multicolumn{2}{|c|}{ Factors } & \multicolumn{2}{|c|}{ Influences } \\
\hline & $N$ & $\%$ & $N$ & $\%$ & $N$ & $\%$ \\
\hline & \multicolumn{6}{|c|}{ Delaware Valley College } \\
\hline Strongly Disagree & 0 & 0.0 & 0 & 0.0 & 0 & 0.0 \\
\hline Disagree & 1 & 50.0 & 1 & 50.0 & 2 & 100.0 \\
\hline Neutral & 1 & 50.0 & 1 & 50.0 & 0 & 0.0 \\
\hline Agree & 0 & 0.0 & 0 & 0.0 & 0 & 0.0 \\
\hline \multirow[t]{2}{*}{ Strongly Agree } & 0 & 0.0 & 0 & 0.0 & 0 & 0.0 \\
\hline & \multicolumn{6}{|c|}{ Pennsylvania State University } \\
\hline Strongly Disagree & 0 & 0.0 & 0 & 0.0 & 0 & 0.0 \\
\hline Disagree & 1 & 50.0 & 0 & 0.0 & 2 & 100.0 \\
\hline Neutral & 1 & 50.0 & 2 & 100.0 & 0 & 0.0 \\
\hline Agree & 0 & 0.0 & 0 & 0.0 & 0 & 0.0 \\
\hline \multirow[t]{2}{*}{ Strongly Agree } & 0 & 0.0 & 0 & 0.0 & 0 & 0.0 \\
\hline & \multicolumn{6}{|c|}{ West Virginia University } \\
\hline Strongly Disagree & 7 & 63.6 & 1 & 9.1 & 0 & 0.0 \\
\hline Disagree & 2 & 18.2 & 2 & 18.2 & 4 & 100.0 \\
\hline Neutral & 2 & 18.2 & 7 & 63.6 & 0 & 0.0 \\
\hline Agree & 0 & 0.0 & 1 & 9.1 & 0 & 0.0 \\
\hline Strongly Agree & 0 & 0.0 & 0 & 0.0 & 0 & 0.0 \\
\hline
\end{tabular}




\section{Chapter V}

\section{Discussion}

Purpose of the Study

The purpose of this study was to provide information to colleges, teacher educators, and school districts regarding common characteristics of pre-service agricultural education teachers who enter teaching and the relationship of the student teaching experience and their decision to teach.

Objectives of the Study

The primary objective of this study was to determine the impact of the student teaching experience upon the decision of the pre-service agricultural education teacher of the Five Star Consortium who graduated from 1998-2001 to enter into teaching.

Secondary objectives for this study were to determine the impact of the personal demographics and the impact of selected factors on the decision of the pre-service agricultural education teachers to enter into teaching.

The primary research question investigated was:

Does the student teaching experience have the greatest impact on the decisions of the preservice agricultural education teacher to enter the teaching profession?

In addition to the primary question, nine alternative questions were considered:

1. Does the gender of the pre-service agricultural education teacher have an impact on his/her decision to enter the teaching profession?

2. Does the upbringing of the pre-service agricultural education teacher have an impact on his/her decision to enter the teaching profession? 
3. Does the age of the pre-service agricultural education teacher have an impact on his/her decision to enter the teaching profession?

4. Does the age of decision of the pre-service agricultural education teacher have an impact on his/her decision to enter the teaching profession?

5. Do the outside influences of the pre-service agricultural education teacher have an impact on his/her decision to enter the teaching profession?

6. Does FFA involvement of the pre-service agricultural education teacher have an impact on his/her decision to enter the teaching profession?

7. Does the number of years in agriculture classes of the pre-service agricultural education teacher have an impact on his/her decision to enter the teaching profession?

8. Do the characteristics of teaching have an impact on the decision of the pre-service agricultural education teacher to enter the teaching profession?

9. Does participation in college organizations have an impact on the decision of the preservice agricultural education teacher to enter the teaching profession?

\section{Limitations of the Study}

This study was limited to the perceptions of pre-service agricultural education teachers from 1998-2001, who attended Delaware Valley College, Pennsylvania State University, and/or West Virginia University.

Design

Descriptive survey research, in the form of a census study, was used to obtain data for this study. 


\section{Population and Sample:}

The target population of this study was the 75 pre-service agricultural education teachers who graduated between 1998-2001 from colleges served by the Five Star Consortium. The total population was determined to be 75 pre-service agricultural education teachers from Delaware Valley College, Pennsylvania State University, and West Virginia University. Lists of preservice agricultural education teachers were secured from the records held within the college's agricultural education departments. Since this study was a census, the frame for this study was the same individuals as the population in which all units (pre-service agricultural education teachers) were included. Two mailed questionnaires were returned as undeliverable from this target population, resulting in an accessible population of $\mathrm{N}=73$.

\section{Instrumentation}

A questionnaire was developed to address the objectives of the study. The questionnaire was modeled after instruments developed by O’Dell, (1982, p. 8) and Ellis (1990, p. 14) and was reviewed by a panel of experts to establish validity. Responses were analyzed for internal consistency reliability using Cronbach's Alpha, which resulted in a reliability coefficient of .78.

\section{Data Collection Procedure}

A two phase descriptive survey was utilized to collect data for the study. The phase one questionnaire, used for respondents to identify the top three reasons why/why not they are teaching, was mailed along with an introductory letter and a self-addressed stamped envelope during the first week of February to pre-service agricultural education teachers in the Five Star Consortium from 1998 to 2001. Follow up post cards were sent to those pre-service agricultural education teachers not responding to the survey two weeks later. Responses from phase one were used to construct the phase two questionnaire. The phase two questionnaire was mailed 
along with an explanatory letter and a self-addressed stamped envelope to the entire population during the first week of March. Follow up post cards were sent to those pre-service agricultural education teachers not responding to the questionnaire a week later. April 10, 2002 was established as the last day responses from the population would be included in this study. Out of the 75 questionnaires mailed, two were returned as undeliverable. Of the 73 remaining questionnaires, 32 (43.84\%) were returned, all of which contained usable data. An analysis of variance was conducted on late and early respondents' replies. No significant difference $(\mathrm{p}<$ .05) was found between the two groups. Based on this the results of the study were assumed to be representative of the entire population.

Analysis of Data

Data collected were analyzed using the Statistical Package for Social Sciences (SPSSPC+) at West Virginia University.

\section{Discussion of Findings}

Institutional data collected in this study were from the three institutions: Delaware Valley College, Pennsylvania State University, and West Virginia University. Over $50 \%$ of the respondents were from West Virginia University and over $40 \%$ of the respondents were from Pennsylvania State University. It is interesting to note that while over $50 \%$ of the respondents came from West Virginia University, only about $30 \%$ of the respondents were currently teaching while over $80 \%$ of the respondents from Pennsylvania State University were currently teaching. These figures may indicate that pre-service agricultural education teachers from Pennsylvania State University have more opportunities to become agriculture teachers and/or there is a higher rollover of teaching positions that occur in Pennsylvania than in West Virginia. 
Demographic data collected in this study were similar to other agricultural education demographic data collected in studies on factors that influence individuals into agricultural education and teaching (Hillison \& Hagee, 1980; Lohman, Kurash, \& Chiu, 1966; Soh, 1983).

Nearly $70 \%$ of the respondents in the study were female and nearly $80 \%$ of the respondents were from a rural upbringing. Interestingly, of the female respondents, less than $50 \%$ were teaching while over $60 \%$ of the male respondents were teaching. The preponderance of the population being female indicates that agricultural education is attracting more females than males but teaching agricultural education attracts a higher percentage of males than females. Another point of interest is that even though West Virginia University had more females in the study than Pennsylvania State University, more of the females from Pennsylvania State University were teaching. Implications from this finding are that females in Pennsylvania State University are more apt to move and get a teaching job than females from West Virginia University. It is also interesting to note that even though nearly $80 \%$ of the respondents were from a rural upbringing, only $50 \%$ were teaching agricultural education while over $60 \%$ of the respondents from an urban upbringing were teaching agricultural education. This distribution of respondents indicates that agricultural education is attracting more individuals from a rural upbringing while teaching agricultural education is attracting more individuals from an urban upbringing.

Over $70 \%$ of the respondents were former members of the FFA. This is an indication that most of the pre-service agricultural education teachers in college were members of the FFA during high school. Of the respondents, over $80 \%$ were members of a college student organization. This indicates that most of the pre-service agricultural education teachers in college have been members of some college student organization. 
The study found that over $90 \%$ of the respondents had positive relationships with their cooperating teacher and their university supervisor during student teaching. Interestingly, even though over $90 \%$ did have a positive relationship with their cooperating teacher and their university supervisor, only $50 \%$ of the respondents were teaching. This implies that a positive relationship with a cooperating teacher and a university supervisor doesn't have a strong impact on the decision of the pre-service agricultural education teacher to enter into teaching.

Over $70 \%$ of the respondents in the study had been enrolled in four years of agricultural classes in high school and over $20 \%$ of the respondents had never been enrolled. Interestingly, less than $40 \%$ of the respondents who had been enrolled in four years of agricultural classes in high school were teaching and over $60 \%$ were not teaching. Of the respondents who had not been enrolled in agricultural classes in high school, over $60 \%$ were currently teaching. These findings imply that enrollment in agricultural classes does not have a strong impact on the decision of pre-service agricultural education teachers to teach and also that increased years in agricultural classes in high school will not have an increased impact on the decision of preservice agricultural education teachers to enter into teaching.

Questions from the teaching section of the questionnaire were divided into five categories, which were: characteristics, personal, location, benefits, and influences. These categories were ranked by respondents who had become teachers, from 1 being strongly disagree to 5 being strongly agree, on the impact that they had on the respondents' decision to teach. The category that had the highest mean rating from the respondents was the characteristics category, which included: love to interact with people, love to work with students, teach life skills to students, and teach proper stewardship. All the 17 respondents from West Virginia and Pennsylvania, strongly agreed or agreed that the characteristics category had an impact on their 
decision to teach. The mean overall response to this category was 4.53 . The average response from West Virginia University was 4.54 and from Pennsylvania State University was 4.53. Interestingly, the characteristics category was the top category for both institutions. This implies that the characteristics of teaching had the greatest impact on pre-service agricultural education teacher's decisions to enter into teaching.

The personal category was rated second highest by the respondents, which included: care about youth, make a difference in students' lives, positive influence on students, enjoy teaching, have fun teaching, have the ability to pass on knowledge, teaching came naturally, teaching was my career dream, and always had desire to teach. Within the 17 respondents, over $80 \%$ of the respondents agreed or strongly agreed that the personal category had an impact on their decision to teach. The average overall response to this category was 3.99. The average response from West Virginia University was 3.93 and from Pennsylvania State University was 4.02. The findings indicate that the items in the personal category had an impact on a pre-service agricultural education teacher to enter into teaching.

The location category had the third highest mean rating from the respondents, which included: live in home community and make a difference in home community. Of the 17 respondents, over $40 \%$ agreed that the location category had an impact on their decision to teach. The average overall response to this category was 3.65. The average response from West Virginia University was 3.42 and from Pennsylvania State University was 3.77. Interestingly, the respondents from West Virginia University ranked this category lower than other categories. The findings indicate that the items in the location category had an impact on a pre-service agricultural education teacher to enter into teaching, and that the location category did not have as much impact on West Virginia University pre-service agricultural education teachers as it did 
on those from Pennsylvania State University. An implication of this finding could be that more pre-service agricultural education teachers from Pennsylvania State University found teaching positions in their home community.

The benefits category was rated third by the respondents, which included: career offers good benefits, career offers insurance protection, career offers good work hours, and career provides vacation time. Of the 17 respondents, over $50 \%$ were neutral that the benefits category had an impact on their decision to teach. The mean overall response to this category was 3.52 . The average response from West Virginia University was 3.58 and from Pennsylvania State University was 3.49. It is interesting to note that respondents from West Virginia University ranked this category above other categories. Implications from these findings could be that preservice agricultural education teachers from West Virginia University are impacted more by the benefits of teaching than are those from Pennsylvania State University.

The influences category had the lowest mean value from the respondents, which include: influenced by other teachers, influenced by high school agriculture teacher, influenced by family, influenced by friends, and enjoyable student teaching experience. Over $40 \%$ agreed or were neutral that the influences category had an impact on their decision to teach. The average response to this category was 3.34. The mean response from West Virginia University was 3.17 and from Pennsylvania State University was 3.44. Interestingly, West Virginia University participants rated this category very low as compared to those from Pennsylvania State University. This finding implies that the influences from teaching had very little impact on the decision of pre-service agricultural education teachers to enter into teaching and that influences from teaching had very little impact on pre-service agricultural education teachers from West 
Virginia University to enter into teaching as compared to those from Pennsylvania State University.

The questions in the non-teaching section of the questionnaire were divided: influences, teaching, and factors. These categories were ranked by respondents, from 1 being strongly disagree to 5 being strongly agree, on the impact that they had on the respondents' decision not to teach. The category rated lowest by the respondents was the influences category, which includes: my friends influenced me, my family influenced me, and my agriculture teacher influenced me. All of the eight respondents disagreed that the influences category had an impact on their decision not to teach. The average response to this category was 1.68 . The average response from West Virginia University was 1.88, from Delaware Valley College was 2.13, and from Pennsylvania State University was 1.57 . These findings imply that the influences category had little impact on their decision to not teach and that there are stronger factors that influence a pre-service agricultural education teacher not to teach.

The teaching category had the second lowest mean rating from the respondents, which includes: not successful, too high expectations, no support from parents, parents questioned my decisions, no administrative support, uncaring administration, too much effort, incompetent administrators, too much politics, needed more flexible schedule, lack of discipline, and too many other demands. Based on the responses from the 15 respondents, over $70 \%$ strongly disagreed or disagreed that the teaching category had an impact on their decision to not teach. The average response to this category was 1.98 . The average response from West Virginia University was 2.62, from Delaware Valley College was 2.73, and from Pennsylvania State University was 1.73 . Implications from the findings are that the teaching category had more of 
an impact on their decision not to teach but was still not a strong factor on the decision of preservice agricultural education teachers to not teach.

The factors category had the highest mean rating from the respondents, which includes: no teaching jobs in local area, got married, not wanting/willing to move, no teaching jobs for spouse, pursuing Master's degree, no teaching jobs open, currently looking for an interesting job perspective, pursuing other career paths, and found an alternate job. Of the 15 respondents, over $60 \%$ were neutral that the factors category had an impact on their decision not to teach. The average response to this category was 2.87. The average response from West Virginia University was 2.75, from Delaware Valley College was 2.75, and from Pennsylvania State University was 2.92. It is of interest to note that even though the average response was higher in value, more of the individuals were neutral that the factors category had an impact on their decision not to teach. Implications from these findings suggest that other factors have stronger impacts on the decisions of pre-service agricultural education teachers to not teach.

\section{Conclusions}

The following conclusions are based on the interpretations of the data presented in this study.

The majority of pre-service agricultural education teachers was female and came from a rural background. Most were members of the FFA in high school and were members of college student organizations. Almost all experienced a positive relationship with their cooperating teacher and their university supervisor during their student teaching.

While more of the pre-service agricultural education teachers were females, the preservice agricultural education teachers that decide to enter the profession were composed of about the same number of males as females. Only half of the pre-service agricultural education 
teachers who were from a rural background decide to enter teaching. More of the pre-service agricultural education teachers who are from an urban background actually decide to enter into teaching. The years of agricultural education classes the pre-service agricultural education teacher is enrolled in through high school is not a strong predictor of the pre-service agricultural education teacher deciding to enter into teaching.

The factors that have the greatest impact on decisions of pre-service agricultural education teachers were included in the characteristics of teaching category. The items in this category were: love to interact with people, love to work with students, teach life skills to students, and teach proper stewardship. The factor that has the strongest impact on the decision of the pre-service agricultural education teacher to enter teaching is the love to interact with people. Other strong factors that impacted the decisions of pre-service agricultural education teachers to enter teaching were: working with students, caring about youth, and making a difference in the lives of students. The characteristics of teaching and the students of teaching impact the decision of pre-service agricultural education teachers to enter teaching more than do the demographics of the pre-service agricultural education teacher.

The non-teaching categories in the study did not have a strong impact on the decisions of pre-service agricultural education teachers to not enter teaching. The two factors that have the strongest impact on the pre-service agricultural education teachers to not teach were lack of jobs in the local area and alternate jobs.

\section{Recommendations}

The following recommendations are based on the results of this study of the impact of student teaching experiences, personal demographics, and selected factors on the decisions of pre-service agricultural education teachers to enter into teaching. 
1. It is recommended that agricultural education departments not focus too narrowly on individuals that have certain demographic characteristics.

2. It is recommended that agricultural education departments use the characteristics of teaching to attract more individuals into agricultural education and into teaching.

3. It is recommended that a longitudinal study be conducted to test for different impacts on the decisions of pre-service agricultural education teachers to enter into teaching.

4. It is recommended that replications of this study be done with a larger population by increasing the number of years and/or areas covered to find common factors that impact the decisions of pre-service agricultural education teachers to enter into teaching.

5. It is recommended that studies using the same population as the one in this study should look more at the factors influencing females from West Virginia University and Pennsylvania State University. 


\section{Bibliography}

American Psychological Association (2001). Publication Manual of the American Psychological Association (5th ed.). Washington, DC. American Psychological Association

Arizona State University, Tempe, College of Education. (n.d.). Professional Field Experiences. Retrieved October 30, 2001, from http://www.ed.asu.edu/coe/pfe/student_teach.htm\#student_teach.

Bass, B. C. (1960). Occupations entered by agricultural education graduates. The Agricultural Education Magazine, 32(12), 284-286.

Bryan, J. E. (1956). Why don't they teach. The Agricultural Education Magazine, 29(6), 137.

Camp, W. G. (2000). A national study of the supply and demand for teachers of agricultural education in 1996-1998. Blacksburg, VA: Virginia Tech., Agricultural Education Program.

Cashwell, C. S. (n.d.). Descriptive research methods. Retrieved April 9, 2002, from Mississippi State University, Department of Counselor Education and Educational Psychology site: http://ericcass.uncg.edu/research/cashwell.html

Clason, D. L. \& Dormody, T. J. (2000). Analyzing data measured by individual Likert-type items. Journal of Agricultural Education, 35(4), 31-35.

Craig, D. G. (1978). Update on vo-ag teacher shortage. The Agricultural Education Magazine, 50(12), 284-285.

Craig, D. G. (1988). Twenty-two year trends in the supply and demand of vocational agriculture teachers. The Agricultural Education Magazine, 60(7), 11-12.

Edwards, M. C., \& Briers, G. E. (2001). Cooperating teachers' perceptions of important elements of the student teaching experience: A focus group approach with quantitative follow-up. Journal of Agricultural Education, 42(3), 31-42.

Ellis, M. P. (2000). Perceived microcomputer education needs of international students enrolled in the West Virginia University College of Agriculture and Forestry. (Master's thesis, West Virginia University, 2000).

Frankiewicz, R. G., \& Merrifield, P. R. (n.d.). Student teacher preferences as predictors of their teaching behavior. (ERIC Document Reproduction Service No. ED011255)

Franklin College, Franklin, (2000-2001). Student Teaching Handbook. Retrieved October 25, 2001, from http://www.franklincoll.edu/eduweb/SecManual/SecondaryHandbook.htm. 
Hammond, L. D. (2000). Solving the dilemmas of teacher supply, demand, and standards: How we can ensure a competent, caring, and qualified teacher for every child. [Electronic version]. The National Commission on Teaching \& America's Future. Retrieved April 7, 2002, from http://www.tc.edu/nctaf/publications/solving.pdf.

Hemp, P. (1957). Who enters teaching. The Agricultural Education Magazine, 29(7), 165-166.

Hillison, J., \& Hagee, G. (1980). A study to determine influencing factors for selecting agricultural education as a career._Blacksburg, VA: Virginia Tech., Agricultural Education Program. (ERIC Document Reproduction Service No. ED195707)

Indiana University, Bloomington, School of Education. (2001, July). Office of Student Teaching. Retrieved October, 30, 2001, from http://education.indiana.edu/ stuteach/.

Indiana University, Bloomington, School of Education. (2001, September). Bilingual/Bicultural Program. Retrieved October, 30, 2001, from http://www.indiana.edu/ bilprog/studentteaching.html.

Indiana University of Pennsylvania, Indiana, College of Education. (n.d.). Preclinical I and II Handbook. Retrieved October 12, 2001, from http://www.coe.iup.edu/ecsp/preclinical.htm.

Ingersoll, R. M. (1995). Teacher supply and demand in the U.S. Paper presented at the annual meeting of the American Statistical Association. (ERIC Document Reproduction Service No. ED415229)

Joerger, R. M. (2002). One key to teacher retention: Understanding the experience and needs of beginning teachers. NAAE News \& Views, 44(2), 6-7.

Liberty Classical School. (n.d.). Educational Quotations. Retrieved April 8, 2002, from http://members.truepath.com/Liberty/page5.html.

Lohman, M. A., Kurash, F, \& Chiu, L. H. (1966). Certain characteristics of student teachers who stay in teaching. (Cooperative Research Project No. S-332). New York, NY: Research Foundation of the City University of New York. (ERIC Document Reproduction Service No. ED010009)

Marymount University, Virginia. (1999, November). Welcome to student teaching at Marymount University. Retrieved October 12, 2001, from http://lists.marymount.edu/ ayoung/student/steach.html.

McCutcheon, J. S. (1995). The relationship between teacher leadership behaviors and experiences and the leadership development taught in high school agriculture education. (Master's thesis, West Virginia University, 1995). 
McGhee, M. B., \& Cheek, J. G. (1990). Assessment of the preparation and career patterns of agricultural education graduates, 1975-1985. Journal of Agricultural Education, 31(2), $17-22$

Moss, J. W., \& Rome, C. (1990). Satisfaction with agricultural education student teaching. Journal of Agricultural Education, 31(2), 29-34.

Muller, J. E., \& Miller, W. W. (1993). Are the more academically able agriculture teacher candidates not entering or remaining in the teaching profession. Journal of Agricultural Education, 34(4), 64-71.

National Center for Education Statistics. (2001). Attrition of new teachers among recent college graduates (NCES Publication No. NCES 2001-189). Washington, DC: U.S. Department of Education.

National Education Association. (n.d.). Teacher shortage. Retrieved October 28, 2001, from http://www.nea.org/teaching/shortage.html.

National Education Association. (1997). Status of the American public school teacher, 1995-96: highlights. Retrieved October 28, 2001, from http://www.nea.org/neatoday/9709/status.html.

Nottis, K., Feurstein, A., \& Murray, J. (2000). The teacher belief inventory: measuring the theoretical and practical orientations of preservice teachers. Retrieved October 25, 2001, from http://www.britannica.com/magazine/article?content_id=266309\&query=teacher\%20beli ef\%20inventory.

O’Dell, I. D. (1982). Problems which restrict the success of agricultural mechanics programs as perceived by West Virginia vocational agriculture teachers. (Master's thesis, West Virginia University, 1982).

Patten, M. L. (2000). Understanding Research Methods (2nd ed.). Los Angeles, CA: Pyrczak Publishing

Payne, C. D., \& Dunkelberger, J. E. (1978). Attraction of youth to the professions: The process of goal identification. (Master's thesis, Auburn University, 1978).

Peak Learning Systems. (2001, October 30). Becoming a teacher. Retrieved October 22, 2001, from http://www.peaklearn.com/newteach/student_teach.html.

Phipps, L. J. (1956). Why teachers make teaching a career. The Agricultural Education Magazine, 29(2), 43-44.

Salant P. \& Dillman D. A. (1994). How to conduct your own survey. New York, NY: John Willey \& Sons, Inc. 
Schwarzweller, H. K., \& Lyson, T. A. (1978). Some plan to become teachers: Determinants of career specification among rural youth in Norway, Germany, and the United States. East Lansing, MI: Department of Sociology. (ERIC Document Reproduction Service No. ED127054)

Smith, B. O., Cohen, S. B., \& Pearl, A. (1969). Teachers for the real world. One Dupont Circle, VA: American Association of Colleges for Teacher Education.

Soh, K. C. (1983). Student-teachers' background and motives for teaching: A 1968-1981 comparison. (Report No. ISBn-9971-953-08-0). Singapore, China: Institute of Education. (ERIC Document Reproduction Service No. ED242676)

Swortzel, K. A. (1998). Differences in reasons why individuals choose to become agricultural teacher educators by demographic characteristics. Journal of Agricultural Education, 39(2), 61-72.

Tabachnick, B. R. (1982). The impact of the student teaching experience on the development of teacher perspectives. (Grant No. NIE-G-81-0009). Washington, D.C.: National Institute of Education. (ERIC Document Reproduction Service No. ED218251)

Unites States Department of Education. (2000). Teacher supply in the United States: Sources of newly hired teachers in public and private schools, 1987-1988 to 1993-1994. Retrieved November 5, 2001, from http://nces.ed.gov/pubs2000/2000309.pdf.

Walsh, K. (2001). Teacher certification reconsidered: Stumbling for quality. Baltimore, MD: The Abell Foundation.

Wayman, W. H. (1982). A history of vocational agriculture 1917-1982. Charleston, WV: West Virginia Department of Education.

Wayne, A. J. (2000). Teacher supply and demand: surprises from primary research. Retrieved January 24, 2002, from http://epaa.asu.edu/epaa/v8n47.html .

West, S. L., Watson, S. B., Thomson, W. S., \& Parke, H. (1993). The effect of the student teaching experience upon preservice elementary teachers' attitude and anxiety involving science and science teaching. Greenville, NC: School of Education. (ERIC Document Reproduction Service No. ED365542)

Wolf, K. (Sen.). (n.d.). Farmland preservation picks up steam. Midwest Stateline. Retrieved April 8, 2002, from http://www.statesnews.org/sic/urban_sprawl/Katie\%20Wolf.pdf

Zelazek, J. R., Williams, W. W., McAdams, C., \& Palmer, K. (1999). 1999 Teacher education follow-up study. Warrensburg, MO: Central Missouri State University. (ERIC Document Reproduction Service No. ED429965) 
Appendices 
Appendix A

A Letter of Introduction mailed with

Phase One Survey 
February 13, 2002

Name

Address

Dear

My undergraduate degree in Agricultural and Environmental Education and my placement as student teacher at Hundred High School played a major role in selecting a topic for my master's thesis research. The variety of student teaching experiences at Hundred High School provided insight into the importance student teaching on an individual's decision to pursue a career as an agricultural education teacher.

After realizing the effect student teaching had on my decisions to teach and discovering the lack of research on the influence student teaching can have on prospective teachers, I decided to conduct a study to determine if student teaching is a major influence on an agricultural education majors' decision to teach. The results of the study will be used to prepare a thesis to partially fulfill the requirements for a Master of Science Degree in Agricultural Education. By determining the impact of the student teaching experience on an individual's decision to teach, modifications could be made to the student teaching experience in an attempt to increase the number of students who will be teachers.

Participants in this research study, while voluntary, will only take a few minutes of your time. On the enclosed form, please list the three top reasons that influenced your decision to enter/not enter a career as an agricultural education teacher. You may skip any question you are not comfortable answering. Please be assured that all information will be held as confidential as possible. Survey results will be reported in a summary format and individual responses will not be identifiable. You will notice a code number at the top right of the first page of the survey. This code will be used to identify non-respondents for follow-up and will be destroyed before the data are analyzed.

A postage-paid self-addressed return envelope is provided for your convenience. Your statements will be combined with those of other past agricultural education graduates from West Virginia University. An edited list will then be sent to you for evaluation and rating of each factor identified.

Participation in the research by returning the questionnaire before February 28, 2002 will be greatly appreciated.

Sincerely,

Gene A. Hovatter Graduate Student
Harry N. Boone

Assistant Professor 


\section{Appendix B}

Phase One Survey 


\section{Top Reasons Why/Why Not Past Agricultural Education Majors Are Teaching}

If you are teaching, please list below the top three reasons why you are currently teaching.

1.

2.

3.

If you are not teaching, please list below the top three reasons why you are not currently teaching.

1.

2.

3.

Please return this form in the enclosed return envelope by February 28, 2002.

I thank you again for your cooperation.

If you would like to be included in the second phase of this study please write your current address on the back of this survey. 
Appendix C

Reminder Post Card

Sent During Phase One 
On February $1^{\text {st }} 2002$, I sent you a questionnaire on the top three reasons why/why not you are teaching. Your reply to this survey will greatly help me to complete my research and thesis. As of today, I have not received your reply. I hope the survey reached you and it is on its way back to me. In the event it is not, please take a few minutes to complete the survey and return it to me. Thanks again for you participation.

If you have questions or comments, please contact me at:

Gene Hovatter

ghovatte@wvu.edu

421 Harding Ave.

Morgantown, WV 26505

304-598-1080 


\section{Appendix D}

A Letter Explanation mailed with

Phase Two Questionnaire 
March 7, 2002

Name

Address

Dear

I would like to thank you for your participation in my study on the importance student teaching has on an individual's decision to pursue a career as an agricultural education teacher. Using a scale of 1 to 5, with 1 being strongly disagree and 5 being strongly agree, please rate the effect each of the statements had on your decision to teach or your decision not to teach. Your assistance in this study is critical to the success of the study, increasing the number and quality of agricultural education graduates, and the completion of my thesis as partial fulfillment of the requirements for a Master of Science Degree in Agricultural Education.

Participation in this research study, while voluntary, will only take a few minutes of your time. You may skip any question you are not comfortable answering. Please be assured that all information will be held as confidential as legally possible. Survey results will be reported in a summary format and individual responses will not be identifiable. You will notice a code number at the top right of the last page of the survey. This code will be used to identify non-respondents for follow-up and will be destroyed before the data are analyzed.

A postage-paid self-addressed return envelope is provided for your convenience in returning the survey. Your answers will be tallied with those of other past agricultural education graduates from West Virginia University, Pennsylvania State University, and Delaware Valley College. The rating of each factor will be identified and then used to draw inferences on their effect on agricultural education graduates to enter into teaching.

Participation in the research by returning the questionnaire before March 14, 2002 will be greatly appreciated.

Sincerely,

Gene A. Hovatter

Graduate Student
Harry N. Boone

Assistant Professor 


\section{Appendix E}

Phase Two Questionnaire 


\section{Student Teaching}

\section{Importance and Impact:}

A survey of past

Agricultural Education

Graduates

Please return your completed questionnaire

in the enclosed envelope to:

The Davis College of Agriculture, Forestry, and Consumer Sciences

West Virginia University $\quad$ PO Box 6108

Morgantown, WV 26506-6108 
Thank you for choosing to complete this questionnaire. Please read and follow the instructions on each section carefully. Circle the number that best describes your rating of the influence each item had on your decision to teach/not to teach agricultural education. A Iso, please complete the background information at the end of the survey instrument.

When you are finished, feel free to $\mathrm{w}$ rite additional comments on the back of the survey and then place the questionnaire in the return envelope and send to my address.

Please turn the page. 
1. I am currently teaching agricultural education.

Yes

No (Proceed to page 5)

Please indicate your level of agreement to each of the following statements by circling the number that best corresponds to your response.

\section{I am currently teaching because:}

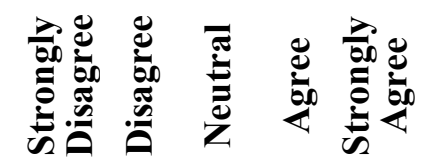

I love to work with students

$\begin{array}{lllll}\mathbf{1} & \mathbf{2} & \mathbf{3} & \mathbf{4} & \mathbf{5} \\ \mathbf{1} & \mathbf{2} & \mathbf{3} & \mathbf{4} & \mathbf{5} \\ \mathbf{1} & \mathbf{2} & \mathbf{3} & \mathbf{4} & \mathbf{5} \\ \mathbf{1} & \mathbf{2} & \mathbf{3} & \mathbf{4} & \mathbf{5} \\ \mathbf{1} & \mathbf{2} & \mathbf{3} & \mathbf{4} & \mathbf{5}\end{array}$

I care about youth

$\begin{array}{lllll}1 & 2 & 3 & 4 & 5\end{array}$

I can make a difference in the life of my students

\begin{tabular}{|c|c|c|c|}
\hline & 2 & 3 & 4 \\
\hline & 2 & 3 & 4 \\
\hline & 2 & 3 & 4 \\
\hline & 2 & 3 & 4 \\
\hline & 2 & 3 & 4 \\
\hline & 2 & 3 & 4 \\
\hline & 2 & 3 & 4 \\
\hline & 2 & 3 & 4 \\
\hline & 2 & 3 & 4 \\
\hline & 2 & 3 & 4 \\
\hline
\end{tabular}

I can make a difference in the community

I teach life skills to my students

I teach proper stewardship to my students

I always had the desire to teach

I enjoy teaching

A teaching career provides vacation time

A teaching career offers good work hours

A teaching career offers good benefits

A teaching career offers insurance protection 


\section{I am currently teaching because:}

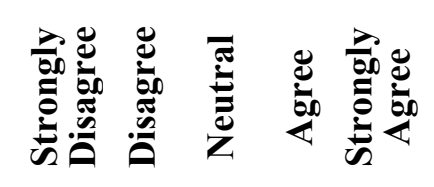

\begin{tabular}{|c|c|c|c|c|}
\hline I have fun teaching & 1 & 2 & 3 & 4 \\
\hline Teaching was my career dream & 1 & 2 & 2 & 4 \\
\hline I can live in my home community & 1 & 2 & 3 & 4 \\
\hline I have the ability to pass on knowledge & 1 & 2 & 3 & 4 \\
\hline $\begin{array}{l}\text { I had an enjoyable student teaching } \\
\text { experience }\end{array}$ & 1 & 2 & 3 & 4 \\
\hline I was influenced by my friends to teach. & 1 & 2 & $\boldsymbol{J}$ & 4 \\
\hline I was influenced by my family to teach. & 1 & 2 & & 4 \\
\hline $\begin{array}{l}\text { I was influenced by my high school } \\
\text { agriculture teacher to teach. }\end{array}$ & 1 & 2 & & 4 \\
\hline $\begin{array}{l}\text { I was influenced by other teachers (other than } \\
\text { the agriculture teacher) to teach. }\end{array}$ & 1 & 2 & y & 4 \\
\hline
\end{tabular}

2. At what approximate age did you decide to teach? Years

\section{(Proceed to page 6 question 3)}




\section{I am currently not teaching because:}

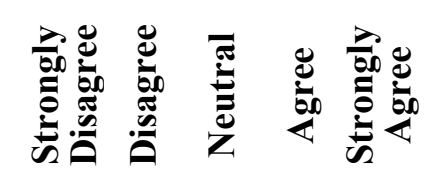

\begin{tabular}{|c|c|c|c|c|}
\hline The stress level was too high & 1 & 2 & 3 & \\
\hline I was not successful & 1 & 7 & & \\
\hline $\begin{array}{l}\text { There were no teaching jobs open in local } \\
\text { area }\end{array}$ & 1 & 2 & 3 & \\
\hline I got married & 1 & 2 & 3 & \\
\hline I was not wanting/willing to move & 1 & 2 & & \\
\hline Teaching has too high expectations & 1 & 2 & & \\
\hline I did not receive support from my parents & 1 & 2 & & \\
\hline $\begin{array}{l}\text { The parents of students constantly questioned } \\
\text { my decisions }\end{array}$ & 1 & 2 & & \\
\hline I did not receive administrative support & 1 & 2 & & \\
\hline My administrators were uncaring & 1 & 2 & & \\
\hline There were no teaching jobs for my spouse & 1 & 2 & & \\
\hline $\begin{array}{l}\text { Teaching requires too much effort for the } \\
\text { rewards }\end{array}$ & 1 & 2 & & \\
\hline $\begin{array}{l}\text { I decided to pursue a Master of Science } \\
\text { degree }\end{array}$ & 1 & 2 & & \\
\hline There were no teaching jobs open & 1 & 2 & & \\
\hline $\begin{array}{l}\text { I am currently looking for an interesting job } \\
\text { perspective }\end{array}$ & 1 & 2 & & \\
\hline
\end{tabular}




\section{I am currently not teaching because:}

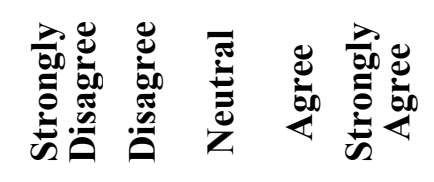

There was too much politics at the state level

I am pursuing another career path(s)

$\begin{array}{lllll}1 & 2 & 3 & 4 & 5\end{array}$

I found an alternate job

$\begin{array}{lllll}1 & 2 & 3 & 4 & 5\end{array}$

I needed a more flexible schedule

$\begin{array}{lllll}1 & 2 & 3 & 4 & 5\end{array}$

There was a lack of discipline in the school system

$\begin{array}{lllll}1 & 2 & 3 & 4 & 5\end{array}$

There was too many demands other than teaching

My friends influenced me not to teach.

My family influenced me not to teach.

$\begin{array}{lllll}1 & 2 & 3 & 4 & 5\end{array}$

My agriculture teacher influenced me not to teach.

$\begin{array}{lllll}1 & 2 & 3 & 4 & 5\end{array}$

$\begin{array}{lllll}1 & 2 & 3 & 4 & 5\end{array}$

$\begin{array}{lllll}1 & 2 & 3 & 4 & 5\end{array}$

$\begin{array}{lllll}1 & 2 & 3 & 4 & 5\end{array}$

3. Were you a member of the FFA back in high school?

$\underset{\text { Nos }}{\mathrm{No}}$

4. How many years of agricultural classes did you take in high school? Years

5. What gender best describes you?

Male

Female 
6. What kind of area did you grow up in?

Rural (farm)

Urban (city or suburbs)

7. What is your current age?

Years

8. During your college education, were you a member of some student organizations?

Yes

No

9. During your student teaching, did you have a positive relationship with your university supervisor?

$$
\text { Yes }
$$

No

10. During your student teaching, did you have a positive relationship with your cooperating teacher?

Yes
No

11. I graduated from:

Delaware Valley College

The Pennsylvania State University

West Virginia University

Other (Please specify

Thank you for taking the time to complete my questionnaire. Feel free to write any comments you may want me to read on the back of this questionnaire. 
Area for comments: 
Appendix F

Reminder Post Card

Sent During Phase Two 
On March 7th 2002, I sent you a booklet questionnaire with multiple reasons why/why not you are teaching. Your quick reply to this survey will greatly help me to complete my research and thesis. As of today, I have not received your reply. I hope the survey reached you and it is on its way back to me. In the event it is not, please take a few minutes to complete the survey and return it to me. Thanks again for your participation.

If you have questions or comments, please contact me at:

Gene Hovatter

ghovatte@wvu.edu

421 Harding Ave.

Morgantown, WV 26505

304-598-1080 


\section{Appendix G}

Distribution of Teaching Responses

From the Questionnaire 
Table G-1

Distribution of Teaching Responses from the Questionnaire

\begin{tabular}{|c|c|c|c|c|c|c|c|c|c|c|c|}
\hline & $\begin{array}{l}\text { Strongly } \\
\text { Disagree }\end{array}$ & & $\begin{array}{r}\text { isagre } \\
\mathrm{e}\end{array}$ & & Neutral & & Agree & & $\begin{array}{r}\text { Strongly } \\
\text { Agree }\end{array}$ & & \\
\hline & $N$ & $\%$ & $N$ & $\%$ & $N$ & $\%$ & $N$ & $\%$ & $N$ & $\%$ & $X$ \\
\hline $\begin{array}{l}\text { Love to Interact with } \\
\text { People }\end{array}$ & 0 & .0 & 0 & .0 & 0 & .0 & 4 & 25.0 & 12 & 75.0 & 4.75 \\
\hline $\begin{array}{l}\text { Love to Work with } \\
\text { Students }\end{array}$ & 0 & .0 & 0 & .0 & 0 & .0 & 6 & 37.5 & 10 & 62.5 & 4.63 \\
\hline Care about Youth & 0 & .0 & 0 & .0 & 0 & .0 & 6 & 37.5 & 10 & 62.5 & 4.63 \\
\hline $\begin{array}{l}\text { Make a Difference in } \\
\text { Students' Lives }\end{array}$ & 0 & .0 & 0 & .0 & 0 & .0 & 6 & 37.5 & 10 & 62.5 & 4.63 \\
\hline $\begin{array}{l}\text { Teach Life Skills to } \\
\text { Students }\end{array}$ & 0 & .0 & 0 & .0 & 0 & .0 & 7 & 43.8 & 9 & 56.3 & 4.56 \\
\hline $\begin{array}{l}\text { Positive Influence on } \\
\text { Students }\end{array}$ & 0 & .0 & 0 & .0 & 0 & .0 & 9 & 56.3 & 7 & 43.8 & 4.44 \\
\hline $\begin{array}{l}\text { Enjoyable Student } \\
\text { Teaching Experience }\end{array}$ & 0 & .0 & 0 & .0 & 1 & 6.3 & 7 & 43.8 & 8 & 50.0 & 4.44 \\
\hline $\begin{array}{l}\text { Teach Proper } \\
\text { Stewardship }\end{array}$ & 0 & .0 & 0 & .0 & 1 & 6.7 & 8 & 53.3 & 6 & 40.0 & 4.33 \\
\hline Enjoy Teaching & 0 & .0 & 0 & .0 & 1 & 6.3 & 9 & 56.3 & 6 & 37.5 & 4.31 \\
\hline $\begin{array}{l}\text { Make a Difference in } \\
\text { Community }\end{array}$ & 0 & .0 & 0 & .0 & 3 & 18.8 & 7 & 43.8 & 6 & 37.5 & 4.19 \\
\hline $\begin{array}{l}\text { Career Offers Good } \\
\text { Benefits }\end{array}$ & 0 & .0 & 0 & .0 & 2 & 12.5 & 10 & 62.5 & 4 & 25.0 & 4.13 \\
\hline Have Fun teaching & 0 & .0 & 0 & .0 & 2 & 12.5 & 10 & 62.5 & 4 & 25.0 & 4.13 \\
\hline $\begin{array}{l}\text { Have the Ability to } \\
\text { Pass on Knowledge }\end{array}$ & 0 & .0 & 0 & .0 & 1 & 6.3 & 13 & 81.3 & 2 & 12.5 & 4.06 \\
\hline $\begin{array}{l}\text { Teaching Came } \\
\text { Naturally }\end{array}$ & 0 & .0 & 1 & 6.3 & 4 & 25.0 & 9 & 56.3 & 2 & 12.5 & 3.75 \\
\hline
\end{tabular}


Table G-1 (Continued)

Distribution of Teaching Responses from the Questionnaire

\begin{tabular}{|c|c|c|c|c|c|c|c|c|c|c|c|}
\hline & $\begin{array}{l}\text { Strongly } \\
\text { Disagree }\end{array}$ & & $\begin{array}{r}\text { isagre } \\
\mathrm{e}\end{array}$ & & Neutral & & Agree & & $\begin{array}{r}\text { Strongly } \\
\text { Agree }\end{array}$ & & \\
\hline & $N$ & $\%$ & $N$ & $\%$ & $N$ & $\%$ & $N$ & $\%$ & $N$ & $\%$ & $X$ \\
\hline $\begin{array}{l}\text { Career Offers } \\
\text { Insurance Protection }\end{array}$ & 0 & .0 & 0 & .0 & 7 & 46.7 & 7 & 46.7 & 1 & 6.7 & 3.60 \\
\hline $\begin{array}{l}\text { Influenced by Other } \\
\text { Teachers }\end{array}$ & 2 & 13.3 & 2 & 13.3 & 3 & 20.0 & 4 & 26.7 & 4 & 26.7 & 3.40 \\
\hline $\begin{array}{l}\text { Influenced by High } \\
\text { School Agr Teacher }\end{array}$ & 3 & 21.4 & 2 & 14.3 & 1 & 7.1 & 3 & 21.4 & 5 & 35.7 & 3.36 \\
\hline $\begin{array}{l}\text { Career Offers Good } \\
\text { Work Hours }\end{array}$ & 2 & 12.5 & 1 & 6.3 & 8 & 50.0 & 2 & 12.5 & 3 & 18.8 & 3.19 \\
\hline $\begin{array}{l}\text { Career Provides } \\
\text { Vacation Time }\end{array}$ & 3 & 18.8 & 1 & 6.3 & 5 & 31.3 & 5 & 31.3 & 2 & 12.5 & 3.13 \\
\hline $\begin{array}{l}\text { Live in Home } \\
\text { Community }\end{array}$ & 2 & 13.3 & 2 & 13.3 & 5 & 33.3 & 5 & 33.3 & 1 & 6.7 & 3.07 \\
\hline $\begin{array}{l}\text { Teaching was my } \\
\text { Career Dream }\end{array}$ & 1 & 6.3 & 4 & 25.0 & 6 & 37.5 & 4 & 25.0 & 1 & 6.3 & 3.00 \\
\hline Influenced by Family & 2 & 12.5 & 5 & 31.3 & 3 & 18.8 & 3 & 18.8 & 3 & 18.8 & 3.00 \\
\hline $\begin{array}{l}\text { Always had Desire to } \\
\text { Teach }\end{array}$ & 2 & 12.5 & 3 & 18.8 & 6 & 37.5 & 4 & 25.0 & 1 & 6.3 & 2.94 \\
\hline Influenced by Friends & 3 & 18.8 & 4 & 25.0 & 7 & 43.8 & 1 & 6.3 & 1 & 6.3 & 2.56 \\
\hline
\end{tabular}




\section{Appendix H}

Distribution of Teaching Responses

In the Influences Category 
Table H-1

Distribution of Teaching Responses in the Influences Category

\begin{tabular}{|c|c|c|c|c|c|c|c|c|c|c|c|}
\hline & \multicolumn{2}{|c|}{$\begin{array}{l}\text { Strongly } \\
\text { Disagree }\end{array}$} & \multicolumn{2}{|c|}{ Disagree } & \multicolumn{2}{|c|}{ Neutral } & \multicolumn{2}{|c|}{ Agree } & \multicolumn{2}{|c|}{$\begin{array}{c}\text { Strongly } \\
\text { Agree }\end{array}$} & \multirow{2}{*}{$\begin{array}{c}\text { Average } \\
\text { Response } \\
X\end{array}$} \\
\hline & $N$ & $\%$ & $N$ & $\%$ & $N$ & $\%$ & $N$ & $\%$ & $N$ & $\%$ & \\
\hline $\begin{array}{l}\text { Influenced by Other } \\
\text { Teachers }\end{array}$ & 2 & 13.3 & 2 & 13.3 & 3 & 20.0 & 4 & 26.7 & 4 & 26.7 & 3.40 \\
\hline $\begin{array}{l}\text { Influenced by High School } \\
\text { Agr Teacher }\end{array}$ & 3 & 21.4 & 2 & 14.3 & 1 & 7.1 & 3 & 21.4 & 5 & 35.7 & 3.36 \\
\hline Influenced by Family & 2 & 12.5 & 5 & 31.3 & 3 & 18.8 & 3 & 18.8 & 3 & 18.8 & 3.00 \\
\hline Influenced by Friends & 3 & 18.8 & 4 & 25.0 & 7 & 43.8 & 1 & 6.3 & 1 & 6.3 & 2.56 \\
\hline $\begin{array}{l}\text { Enjoyable Student } \\
\text { Teaching Experience }\end{array}$ & 0 & .0 & 0 & .0 & 1 & 6.3 & 7 & 43.8 & 8 & 50.0 & 4.44 \\
\hline
\end{tabular}




\section{Appendix I}

Distribution of Teaching Responses

In the Location Category 
Table I-1

Distribution of Teaching Responses in the Location Category

\begin{tabular}{lrrrrrrrrrrrr}
\hline & $\begin{array}{c}\text { Strongly } \\
\text { Disagree }\end{array}$ & Disagree & Neutral & Agree & $\begin{array}{c}\text { Strongly } \\
\text { Agree }\end{array}$ & $\begin{array}{c}\text { Average } \\
\text { Response }\end{array}$ \\
\hline & $N$ & $\%$ & $N$ & $\%$ & $N$ & $\%$ & $N$ & $\%$ & $N$ & $\%$ & $X$ \\
\hline $\begin{array}{l}\text { Live in Home Community } \\
\text { Make a Difference in }\end{array}$ & 2 & 13.3 & 2 & 13.3 & 5 & 33.3 & 5 & 33.3 & 1 & 6.7 & 3.07 \\
Community & .0 & 0 & .0 & 3 & 18.8 & 7 & 43.8 & 6 & 37.5 & 4.19 \\
\hline
\end{tabular}




\section{Appendix J}

Distribution of Teaching Responses

In the Benefits Category 
Table J-1

Distribution of Teaching Responses in the Benefits Category

\begin{tabular}{|c|c|c|c|c|c|c|c|c|c|c|c|}
\hline & \multicolumn{2}{|c|}{$\begin{array}{l}\text { Strongly } \\
\text { Disagree }\end{array}$} & \multicolumn{2}{|c|}{ Disagree } & \multicolumn{2}{|c|}{ Neutral } & \multicolumn{2}{|c|}{ Agree } & \multicolumn{2}{|c|}{$\begin{array}{l}\text { Strongly } \\
\text { Agree }\end{array}$} & \multirow{2}{*}{$\begin{array}{c}\text { Average } \\
\text { Response } \\
X\end{array}$} \\
\hline & $N$ & $\%$ & $N$ & $\%$ & $N$ & $\%$ & $N$ & $\%$ & $N$ & $\%$ & \\
\hline $\begin{array}{l}\text { Career Offers Good } \\
\text { Benefits }\end{array}$ & 0 & .0 & 0 & .0 & 2 & 12.5 & 10 & 62.5 & 4 & 25.0 & 4.13 \\
\hline $\begin{array}{l}\text { Career Offers Insurance } \\
\text { Protection }\end{array}$ & 0 & .0 & 0 & .0 & 7 & 46.7 & 7 & 46.7 & 1 & 6.7 & 3.60 \\
\hline $\begin{array}{l}\text { Career Offers Good Work } \\
\text { Hours }\end{array}$ & 2 & 12.5 & 1 & 6.3 & 8 & 50.0 & 2 & 12.5 & 3 & 18.8 & 3.19 \\
\hline $\begin{array}{l}\text { Career Provides Vacation } \\
\text { Time }\end{array}$ & 3 & 18.8 & 1 & 6.3 & 5 & 31.3 & 5 & 31.3 & 2 & 12.5 & 3.13 \\
\hline
\end{tabular}


Appendix K

Distribution of Teaching Responses

In the Characteristics Category 
Table K-1

Distribution of Teaching Responses in the Characteristics Category

\begin{tabular}{|c|c|c|c|c|c|c|c|c|c|c|c|}
\hline & \multicolumn{2}{|c|}{$\begin{array}{l}\text { Strongly } \\
\text { Disagree }\end{array}$} & \multicolumn{2}{|c|}{ Disagree } & \multicolumn{2}{|c|}{ Neutral } & \multicolumn{2}{|c|}{ Agree } & \multicolumn{2}{|c|}{$\begin{array}{l}\text { Strongly } \\
\text { Agree }\end{array}$} & \multirow{2}{*}{$\begin{array}{c}\text { Average } \\
\text { Response } \\
X\end{array}$} \\
\hline & $N$ & $\%$ & $N$ & $\%$ & $N$ & $\%$ & $N$ & $\%$ & $N$ & $\%$ & \\
\hline $\begin{array}{l}\text { Love to Interact with } \\
\text { People }\end{array}$ & 0 & .0 & 0 & .0 & 0 & .0 & 4 & 25.0 & 12 & 75.0 & 4.75 \\
\hline $\begin{array}{l}\text { Love to Work with } \\
\text { Students }\end{array}$ & 0 & .0 & 0 & .0 & 0 & .0 & 6 & 37.5 & 10 & 62.5 & 4.63 \\
\hline $\begin{array}{l}\text { Teach Life Skills to } \\
\text { Students }\end{array}$ & 0 & .0 & 0 & .0 & 0 & .0 & 7 & 43.8 & 9 & 56.3 & 4.56 \\
\hline Teach Proper Stewardship & 0 & .0 & 0 & .0 & 1 & 6.7 & 8 & 53.3 & 6 & 40.0 & 4.33 \\
\hline
\end{tabular}


Appendix L

Distribution of Teaching Responses

In the Personal Category 
Table L-1

Distribution of Teaching Responses in the Personal Category

\begin{tabular}{|c|c|c|c|c|c|c|c|c|c|c|c|}
\hline & \multicolumn{2}{|c|}{$\begin{array}{l}\text { Strongly } \\
\text { Disagree }\end{array}$} & \multicolumn{2}{|c|}{ Disagree } & \multicolumn{2}{|c|}{ Neutral } & \multicolumn{2}{|c|}{ Agree } & \multicolumn{2}{|c|}{$\begin{array}{l}\text { Strongly } \\
\text { Agree }\end{array}$} & \multirow{2}{*}{$\begin{array}{c}\text { Average } \\
\text { Response } \\
X\end{array}$} \\
\hline & $N$ & $\%$ & $N$ & $\%$ & $N$ & $\%$ & $N$ & $\%$ & $N$ & $\%$ & \\
\hline Care about Youth & 0 & .0 & 0 & .0 & 0 & .0 & 6 & 37.5 & 10 & 62.5 & 4.63 \\
\hline $\begin{array}{l}\text { Make a Difference in } \\
\text { Students' Lives }\end{array}$ & 0 & .0 & 0 & .0 & 0 & .0 & 6 & 37.5 & 10 & 62.5 & 4.63 \\
\hline $\begin{array}{l}\text { Positive Influence on } \\
\text { Students }\end{array}$ & 0 & .0 & 0 & .0 & 0 & .0 & 9 & 56.3 & 7 & 43.8 & 4.44 \\
\hline Enjoy Teaching & 0 & .0 & 0 & .0 & 1 & 6.3 & 9 & 56.3 & 6 & 37.5 & 4.31 \\
\hline Have Fun teaching & 0 & .0 & 0 & .0 & 2 & 12.5 & 10 & 62.5 & 4 & 25.0 & 4.13 \\
\hline $\begin{array}{l}\text { Have the Ability to Pass on } \\
\text { Knowledge }\end{array}$ & 0 & .0 & 0 & .0 & 1 & 6.3 & 13 & 81.3 & 2 & 12.5 & 4.06 \\
\hline Teaching Came Naturally & 0 & .0 & 1 & 6.3 & 4 & 25.0 & 9 & 56.3 & 2 & 12.5 & 3.75 \\
\hline $\begin{array}{l}\text { Teaching was my Career } \\
\text { Dream }\end{array}$ & 1 & 6.3 & 4 & 25.0 & 6 & 37.5 & 4 & 25.0 & 1 & 6.3 & 3.00 \\
\hline $\begin{array}{l}\text { Always had Desire to } \\
\text { Teach }\end{array}$ & 2 & 12.5 & 3 & 18.8 & 6 & 37.5 & 4 & 25.0 & 1 & 6.3 & 2.94 \\
\hline
\end{tabular}




\section{Appendix M}

\section{Distribution of Non-teaching Responses}

From the Questionnaire 
Table M-1

Distribution of Non-teaching Responses from the Questionnaire

\begin{tabular}{|c|c|c|c|c|c|c|c|c|c|c|}
\hline & $\begin{array}{l}\text { Strongly } \\
\text { Disagree }\end{array}$ & & Disagree & & Neutral & & Agree & & $\begin{array}{l}\text { Strongly } \\
\text { Agree }\end{array}$ & \\
\hline & Count & $\%$ & Count & $\%$ & Count & $\%$ & Count & $\%$ & Count & $\%$ \\
\hline Stress Level too High & 5 & 33.3 & 3 & 20.0 & 5 & 33.3 & 2 & 13.3 & & \\
\hline Not Successful & 10 & 66.7 & 4 & 26.7 & 1 & 6.7 & & & & \\
\hline No Jobs in Local Area & 2 & 13.3 & 2 & 13.3 & 1 & 6.7 & 4 & 26.7 & 6 & 40.0 \\
\hline Married & 7 & 46.7 & 1 & 6.7 & 3 & 20.0 & 1 & 6.7 & 3 & 20.0 \\
\hline Not Willing to Move & 5 & 33.3 & 2 & 13.3 & 3 & 20.0 & 3 & 20.0 & 2 & 13.3 \\
\hline Too High Expectations & 8 & 53.3 & 5 & 33.3 & 2 & 13.3 & & & & \\
\hline No Support from Parents & 14 & 93.3 & 1 & 6.7 & & & & & & \\
\hline $\begin{array}{l}\text { Parents Questioned } \\
\text { Decisions }\end{array}$ & 9 & 60.0 & 3 & 20.0 & 2 & 13.3 & 1 & 6.7 & & \\
\hline No Administrative Support & 6 & 40.0 & 4 & 26.7 & 1 & 6.7 & 3 & 20.0 & 1 & 6.7 \\
\hline Uncaring Administrators & 7 & 46.7 & 3 & 20.0 & 2 & 13.3 & 2 & 13.3 & 1 & 6.7 \\
\hline No Job for Spouse & 10 & 76.9 & & & 2 & 15.4 & & & 1 & 7.7 \\
\hline $\begin{array}{l}\text { Too Much Effort for } \\
\text { Rewards }\end{array}$ & 8 & 53.3 & 1 & 6.7 & 1 & 6.7 & 4 & 26.7 & 1 & 6.7 \\
\hline Pursued Masters Degree & 6 & 40.0 & 2 & 13.3 & 3 & 20.0 & & & 4 & 26.7 \\
\hline No Teaching Jobs Open & 3 & 20.0 & 3 & 20.0 & 4 & 26.7 & 2 & 13.3 & 3 & 20.0 \\
\hline $\begin{array}{l}\text { Looking for Interesting Job } \\
\text { Prospect }\end{array}$ & 5 & 33.3 & 2 & 13.3 & 3 & 20.0 & 4 & 26.7 & 1 & 6.7 \\
\hline $\begin{array}{l}\text { Incompetent School } \\
\text { Administrators }\end{array}$ & 9 & 60.0 & 2 & 13.3 & 1 & 6.7 & 2 & 13.3 & 1 & 6.7 \\
\hline Too Much State Politics & 6 & 40.0 & 2 & 13.3 & 4 & 26.7 & 3 & 20.0 & & \\
\hline $\begin{array}{l}\text { Pursuing Another Career } \\
\text { Path }\end{array}$ & 4 & 26.7 & & & 3 & 20.0 & 7 & 46.7 & 1 & 6.7 \\
\hline Found Alternate Job & 2 & 13.3 & & & 2 & 13.3 & 6 & 40.0 & 5 & 33.3 \\
\hline $\begin{array}{l}\text { Need More Flexible } \\
\text { Schedule }\end{array}$ & 7 & 46.7 & 1 & 6.7 & 4 & 26.7 & 3 & 20.0 & & \\
\hline
\end{tabular}


Table M-1 (Continued)

Distribution of Non-teaching Responses from the Questionnaire

\begin{tabular}{|c|c|c|c|c|c|c|c|c|c|c|}
\hline & $\begin{array}{l}\text { Strongly } \\
\text { Disagree }\end{array}$ & & Disagree & & Neutral & & Agree & & $\begin{array}{l}\text { Strongly } \\
\text { Agree }\end{array}$ & \\
\hline & Count & $\%$ & Count & $\%$ & Count & $\%$ & Count & $\%$ & Count & $\%$ \\
\hline $\begin{array}{l}\text { Lack of Discipline in School } \\
\text { System }\end{array}$ & 5 & 33.3 & 2 & 13.3 & 4 & 26.7 & 4 & 26.7 & & \\
\hline $\begin{array}{l}\text { Too Many Demands Other } \\
\text { Than Teaching }\end{array}$ & 6 & 40.0 & 4 & 26.7 & 1 & 6.7 & 4 & 26.7 & & \\
\hline $\begin{array}{l}\text { Friends Influenced "No" } \\
\text { Decision }\end{array}$ & 12 & 80.0 & 2 & 13.3 & 1 & 6.7 & & & & \\
\hline $\begin{array}{l}\text { Family Influenced "No" } \\
\text { Decision }\end{array}$ & 12 & 80.0 & 2 & 13.3 & 1 & 6.7 & & & & \\
\hline $\begin{array}{l}\text { Agr Teacher Influenced "No" } \\
\text { Decision }\end{array}$ & 14 & 93.3 & & & 1 & 6.7 & & & & \\
\hline
\end{tabular}




\section{Appendix N}

\section{Distribution of Non-teaching Responses}

In the Teaching Category 
Table N-1

Distribution of Non-teaching Responses in the Teaching Category

\begin{tabular}{|c|c|c|c|c|c|c|c|c|c|c|}
\hline & $\begin{array}{l}\text { Strongly } \\
\text { Disagree }\end{array}$ & & Disagree & & Neutral & & Agree & & $\begin{array}{l}\text { Strongly } \\
\text { Agree }\end{array}$ & \\
\hline & Count & $\%$ & Count & $\%$ & Count & $\%$ & Count & $\%$ & Count & $\%$ \\
\hline Stress Level too High & 5 & 33.3 & 3 & 20.0 & 5 & 33.3 & 2 & 13.3 & & \\
\hline Too High Expectations & 8 & 53.3 & 5 & 33.3 & 2 & 13.3 & & & & \\
\hline No Support from Parents & 14 & 93.3 & 1 & 6.7 & & & & & & \\
\hline Parents Questioned Decisions & 9 & 60.0 & 3 & 20.0 & 2 & 13.3 & 1 & 6.7 & & \\
\hline Too Much Effort for Rewards & 8 & 53.3 & 1 & 6.7 & 1 & 6.7 & 4 & 26.7 & 1 & 6.7 \\
\hline Incompetent School Administrators & 9 & 60.0 & 2 & 13.3 & 1 & 6.7 & 2 & 13.3 & 1 & 6.7 \\
\hline Too Much State Politics & 6 & 40.0 & 2 & 13.3 & 4 & 26.7 & 3 & 20.0 & & \\
\hline Need More Flexible Schedule & 7 & 46.7 & 1 & 6.7 & 4 & 26.7 & 3 & 20.0 & & \\
\hline Lack of Discipline in School System & 5 & 33.3 & 2 & 13.3 & 4 & 26.7 & 4 & 26.7 & & \\
\hline $\begin{array}{l}\text { Too Many Demands Other Than } \\
\text { Teaching }\end{array}$ & 6 & 40.0 & 4 & 26.7 & 1 & 6.7 & 4 & 26.7 & & \\
\hline
\end{tabular}




\section{Appendix O}

Distribution of Non-teaching Responses

In the Factors Category 
Table O-1

Distribution of Non-teaching Responses in the Factors Category

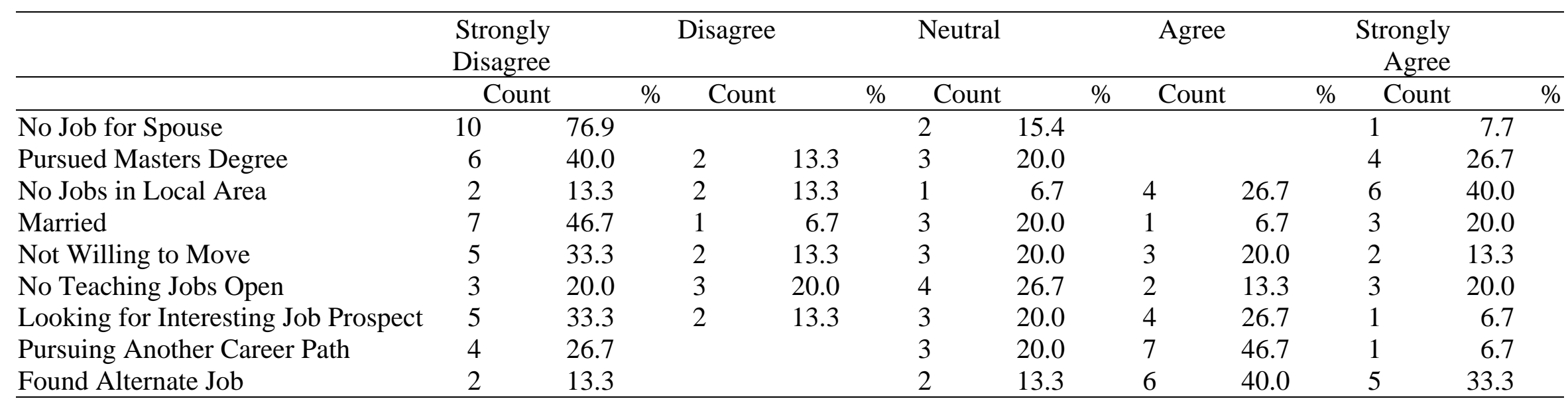




\section{Appendix P}

Distribution of Non-teaching Responses

In the Influences Category 
Table P-1

Distribution of Non-teaching Responses in the Influences Category

\begin{tabular}{|c|c|c|c|c|c|c|c|c|c|c|}
\hline & $\begin{array}{l}\text { Strongly } \\
\text { Disagree }\end{array}$ & & Disagree & & Neutral & & Agree & & $\begin{array}{l}\text { Strongly } \\
\text { Agree }\end{array}$ & \\
\hline & Count & $\%$ & Count & $\%$ & Count & $\%$ & Count & $\%$ & Count & $\%$ \\
\hline Friends Influenced "No" Decision & 12 & 80.0 & 2 & 13.3 & 1 & 6.7 & & & & \\
\hline $\begin{array}{l}\text { Agr Teacher Influenced "No" } \\
\text { Decision }\end{array}$ & 14 & 93.3 & & & 1 & 6.7 & & & & \\
\hline
\end{tabular}


Appendix Q

Comments from Respondents

To the Questionnaire 
This survey came at a time when I am struggling about if this is the type of job I really want to pursue. There are so many demands on an agriculture teacher, especially with the FFA! Also, I'd like to farm, and it's very difficult to find the ideal balance. Thank you for taking this opportunity to ask these kinds of questions. Hopefully, your findings will be forwarded to the National FFA, NATA, etc....

Sorry about this survey many items however were not applicable to my situation. I can't agree or disagree if I have no experience with that item.

Teaching was a very rewarding experience. I do miss the students and experiences. I do enjoy my current job as a county 4-H agent.

My goal was not to teach agriculture, I wanted to teach general science/environmental science. This degree (AEE) allows me to do this. Good luck with your survey. I'm currently doing the same project at Holy Family.

My dream as a future Ag. Teacher would love to see that the state of WV that agricultural education should be a requirement in middle junior high school and high school. At least 1 year in each school. This will open up more jobs for perspective ag. Teachers and graduated agricultural education majors to look forward to getting a job in the field they went and graduated college for. It is discouraging at times, that there is limited ag education jobs in the area or surrounding areas that you live in.

Sorry so late in return but I received it in the mail on the $14^{\text {th }} \rightarrow$ Snail mail in my area is horrible.

I don't like when they say survey but you know who the surveyors are! Taking away my legal rights.

FFA and SAE are difficult to teach not having an ag. background.

I am currently substituting and find all teaching worthwhile. Although I am certified in Ag. Ed., it is the students, not the subject matter I find rewarding. However, teaching ag. is easier than other subjects. 
Appendix R

Copy of Approval from

The Institutional Review Board for

The Protection of Human Subjects 
MEMORA NDUM

To: Gene Hovatter

College of Agriculture, Forestry, \& Consumer Sciences

Division of Resource Managernent

From: Marian J. Turner

Senior Program Coordinator

for Regulatory Compliance

Re: $\quad$ HS \# 15380-E; Impact of Student Teaching Experiences, Personal Demographics, and Selected Factors on the Decisions of Past Graduates of Agricultural Education to Teach

The Institutional Review Board for the Protection of Hurman Subjects has reviewed and approved the Application for Exemption for the above named research project.

This exemption approval will remain in effect only on the condition that the research is carried out exactly as described in the Application and will be valid for one year from the date above. Please contact the IRB office before the anniversary date, if you wish to apply for renewal

Best wishes for the success of your research.

MJThaw 


\section{Vita}

July 13, 1979

June, 1997

May, 2001

August, 2001 to

May, 2002

May, 2002
Born: Moatsville, West Virginia

Graduated - Philip Barbour High School Philippi, West Virginia

Bachelor of Science in Agriculture Agricultural and Environmental Education West Virginia University Morgantown, West Virginia

Graduate Teaching Assistant Agriculture and Environmental Education West Virginia University Morgantown, West Virginia

Master of Science Agricultural and Environmental Education West Virginia University Morgantown, West Virginia 